\title{
THE INFLUENCE OF RE-SELECTION ON INDEPENDENT DECISION MAKING IN STATE SUPREME COURTS
}

\author{
Hon. Justice AnN A. SCOTt TIMMER*
}

\begin{abstract}
I
INTRODUCTION

Soon after I was appointed to the Arizona Court of Appeals in 2000, I attended a two-week session for new appellate court judges at the National Judicial College in Reno, Nevada. Among the speakers was former Tennessee Supreme Court Justice Penny White, who spoke about the need to consider how language used in opinions is understood by the public. She related her experience of losing her retention election in 1996 in the wake of the Tennessee Supreme Court's controversial decision reversing a death sentence. Justice White pointed out that some language used in the opinion-for example, stating that the murder of a grandmother wasn't "cruel" - was misunderstood and prompted misplaced outrage. Justice White's message was to be careful with word choices. My takeaway was that Justices could be fired for doing their jobs if the public is unhappy with a single opinion. Having just surrendered a lucrative law practice to take the bench, I found Justice White's cautionary tale chilling.

As the years progressed and I found myself deciding publicly controversial cases, the ghost of Justice White's retention loss occasionally hovered in my peripheral vision, taking more definite shape at times-for example when three Iowa Supreme Court Justices lost their retention elections in 2010 following a divisive same-sex marriage decision. But whenever that menace reappeared, I consciously, and hopefully successfully, banished it by considering the importance of adhering to my oath of office, preserving my integrity, and reminding myself that the worst thing that could happen is that I would be voted out of office and forced to return to the practice of law with my head held high.
\end{abstract}

Copyright (C) 2019 by Hon. Justice Ann A. Scott Timmer.

This article is also available online at http://lcp.law.duke.edu/.

* Ann A. Scott Timmer has served as a Justice on the Arizona Supreme Court from 2012 to the present. Effective July 1, 2019, she will serve as Vice Chief Justice. She is grateful for the assistance of externs Blake Moscatello and Tami Seekins in compiling empirical information useful to her research. 


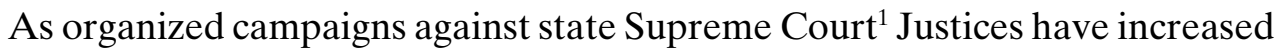
in recent years, ${ }^{2}$ particularly with the proliferation of dark money contributions and social media, I have pondered the effect on sitting Justices. Ask people what they desire in a Justice and they most likely say something that suggests a fair and independent decision-maker. But do our judicial re-selection methods pressure Justices to consider their personal welfare when making decisions at the cost of independence?

This article does not focus on reforming existing methods for re-selecting state Supreme Court Justices. Rather, I seek to add to our knowledge of how current re-selection systems affect sitting Justices. After a historical overview of how the states choose to select and retain Supreme Court Justices, I hypothesize that the re-selection methods-elections and reappointments-imposed on most Justices tempt them to act strategically to maximize their prospects of maintaining their positions. To test this hypothesis, I gathered evidence from confidential interviews conducted with sitting and retired state Supreme Court Justices and federal court judges who formerly served in state courts. To further test the hypothesis, I also propose as a sub-hypothesis that Justices concerned with re-selection act strategically in dissenting or specially concurring. To test this sub-hypothesis, I examine two empirical measures: (1) Justices' overall dissent and special concurrence rates the year before a re-selection event as compared with the rate the year after; and (2) Justices' criminal dissent and special concurrence rates the year before a re-selection event as compared with the rate the year following re-selection.

\section{II}

BALANCING JUDICIAL INDEPENDENCE WITH DEMOCRATIC ACCOUNTABILITY: A HISTORICAL OVERVIEW

The Eighteenth Century American colonists so resented King George III's exercise of power to appoint and remove judges that the Declaration of Independence lists as a grievance that the King "has made judges depend on his will alone, for the tenure of their offices, and the amount and payment of their salaries." ${ }^{3}$ To protect judicial independence, the framers of the United States Constitution empowered the President to appoint federal judges, with Senate

1. Texas and Oklahoma have two courts of last resort, one for civil appeals and one for criminal appeals. Other states have courts of appeals as courts of last resort. For ease of reference, I refer to each court of last resort as a "Supreme Court." See Court of Last Resort, BALlOTPEDIA, https://ballotpedia.org/Court_of_last_resort [https://perma.cc/FQK2-DRRW] (last visited Sept. 22, 2018).

2. See, e.g. JoAnna ShePerd, Justice At Risk: An EMPIRICAl ANAlysis Of CAMPaign CONTRIBUTIONS AND JUDICIAL DECISIONS 6 (2013), https://www.acslaw.org/wpcontent/uploads/olduploads/originals/documents/JusticeAtRisk_Nov2013.pdf [https://perma.cc/2ARG-YDV4].

3. Joseph R. Grodin, Developing a Consensus of Constraint: A Judge's Perspective on Judicial Retention Elections, 61 S. CAL. L. REV. 1969, 1970 (1988) (quoting THE DeClaration OF INDEPENDENCE para. 11 (U.S. 1776)). 
approval, for lifetime tenures. ${ }^{4}$ Likewise, the majority of states provided lifetime appointments for judges, constrained only by the requirement of good behavior. ${ }^{5}$ Judicial elections were rare during the country's fledgling years. ${ }^{6}$

In a wave of populist sentiment, states turned to electing judges in the first half of the $1800 \mathrm{~s}$, believing that elected judges would be more accountable to the public than appointed judges. ${ }^{7}$ Jacksonian populism fizzled, but more states turned to electing judges in the mid-1800s "based on the theory that 'elected judges who derived their authority from the people would be more independentminded than hand-picked friends of governors or jurists subject to the beck and call of the legislature."' These reforms were largely successful, and by the start of the Civil War, the majority of states elected their judges. ${ }^{9}$

The pendulum swung away from electing judges in the first part of the 1900s with the advent of the "merit selection" system for selecting judges. ${ }^{10}$ Reformers had become concerned that electing judges did not result in seating legally competent jurists and gave political party bosses the power to hand pick successful judicial candidates, thereby threatening their independence. ${ }^{11}$

In a typical merit selection system, an independent citizen commission recommends several candidates and, "[f]rom this pool, the Governor appoints a judge." 12 After a period of time, voters decide whether the judge should be retained in office. ${ }^{13}$ Thereafter, the judge runs for reelection at regular intervals in uncontested retention elections. ${ }^{14}$ Today, twenty-one states select Justices through partisan ${ }^{15}$ or non-partisan elections, ${ }^{16}$ although Justices may be

4. Sandra Day O'Connor \& RonNell Andersen Jones, Reflections on Arizona's Judicial Selection Process, 50 ARIZ. L. REV. 15, 16 (2008).

5. Grodin, supra note 3, at 1970. In the original thirteen states, either the legislature or the governor appointed the judges. Diane M. Johnsen, Building a Bench: A Close Look at State Appellate Courts Constructed by the Respective Methods of Judicial Selection, 53 SAN DIEGO L. REV. 829, 836 (2016).

6. O'Connor \& Jones, supra note 4, at 16.

7. Id. Georgia became the first state to use elections to select judges when it amended its constitution in 1812. Id.

8. Id. at 1617 (quoting Charles Gardner Geyh, An Overview of State Judicial Selection Systems and Their Relationship to Judicial Independence, in SANDRA DAY O'CONNOR PROJECT ON THE STATE OF THE JUdiCIARY, BACKGROUND PAPERS FOR 2007 CONFERENCE: THE DEBATE OVER Judicial ELECTIONS AND STATE COURT JUdiCIAL SELECTION, 7 (Georgetown Law, 2007)).

9. Id. at 17 .

10. $I d$.

11. Id.

12. $I d$.

13. Id.

14. Johnsen, supra note 5, at 837.

15. Alabama, Illinois, Louisiana, New Mexico, Pennsylvania, Texas.

16. Arkansas, Georgia, Idaho, Kentucky, Michigan, Minnesota, Mississippi, Montana, Nevada, North Carolina, North Dakota, Ohio, Oregon, Washington, West Virginia, and Wisconsin. New Mexico's system is unique. After a Justice is elected in a partisan election, the Justice thereafter runs periodically in retention elections. 
appointed to fill mid-term vacancies. ${ }^{17}$ The remaining twenty-nine states ${ }^{18}$ and the District of Columbia use a form of merit selection, gubernatorial appointment, or legislative appointment to initially select Justices for their Supreme Courts. ${ }^{19}$ Only a handful of states provide lifetime or near-lifetime tenures for Justices, subject to good behavior requirements. ${ }^{20}$ Sitting Justices in the remaining states and the District of Columbia must be reappointed or run in retention, partisan, or non-partisan elections. ${ }^{21}$

The variety of systems currently used by the states reflects a lack of consensus about the best way to choose Supreme Court Justices. The debate generally focuses on how to preserve judicial independence while holding Justices democratically accountable. ${ }^{22}$

\section{III}

\section{THE MODERN REALITY: TURNING UP THE PRESSURE ON SITTING JUSTICES}

A consistent goal of all judicial selection and re-selection systems is a desire to select and retain judges who independently exercise judgment to interpret and apply the law and yet remain accountable for their performances. ${ }^{23}$ Since the 1980s, however, these systems have become increasingly politicized as special interest groups grasped that "investing in judicial races - often by funding ads urging voters to hold judges accountable for rulings in controversial cases - is an inexpensive way to shape policy: cheaper than lobbying, cheaper than supporting the campaigns of governors and state legislators." 24

17. See BALlotPediA, supra note 2 .

18. Alaska, Arizona, California, Colorado, Connecticut, Delaware, Florida, Hawaii, Indiana, Iowa, Kansas, Maine, Maryland, Massachusetts, Missouri, Nebraska, New Hampshire, New Jersey, New York, Oklahoma, Rhode Island, South Carolina South Dakota, Tennessee, Utah, Vermont, Virginia, and Wyoming.

19. See BALlotPEDiA, supra note 2 .

20. Massachusetts, New Hampshire and Rhode Island provide lifetime tenure or tenure until a specific age. In New Jersey, the Governor can confer lifetime tenure after the Justice has served seven years after appointment. See BALLOTPEDIA, supra note 2.

21. See BALlotPEDiA, supra note 2. For ease of reference, I collectively refer to reappointment, retention elections, and partisan and non-partisan re-elections as "re-selection" or "re-selection events." Unless otherwise noted, I also include the District of Columbia within the meaning of "state" or "states."

22. ADAM BONICA AND MiCHAEL J. WOODRUFF, STATE SUPREME COURT IDEOLOGY AND "NEW STYLE" JUDICIAL CAMPAIGNS 1 (2012), https://ssrn.com/abstract=2169664 [https://perma.cc/GC7K-NB6T] or http://dx.doi.org/10.2139/ssrn.2169664 [https://perma.cc/HF5BMXNJ].

23. See JOHN F. KOWAL, New IDEAS FOR A NEW DEMOCRACY: JUdiCIAL SELECTION FOR THE $21^{\text {st }}$ CENTURY 4 (2016), https://www.brennancenter.org/sites/default/files/publications/Judicial_ Selection_21st_Century.pdf [https://perma.cc/22W4-FHCS] ("But they were all intended to ensure an appropriate balance of independence and accountability."); Anthony J. Delligatti, A Horse of a Different Color: Distinguishing the Judiciary from the Political Branches in Campaign Financing, 115 W. VA. L. REV. 401, 414 (2012) (noting that arguments supporting the various methods of judicial selection used throughout different time periods have been public accountability, free speech, and judicial independence).

24. KOWAL, supra note 23 , at 1 . 
Money has progressively poured into judicial elections. A series of United States Supreme Court decisions, starting with Citizens United v. Federal Election Commission, have permitted dark money ${ }^{25}$ to fund attack ads on sitting Justices and reined in efforts to protect publicly financed candidates from being outspent. ${ }^{26}$ "From 2000-2009, state supreme court candidates raised \$206.9 million, more than doubling the $\$ 83.3$ million raised in the prior decade." ${ }^{27}$ In 2013-14 alone, spending in nineteen state Supreme Court elections exceeded $\$ 34.5$ million. ${ }^{28}$ Retention elections, once considered non-political, have become battlegrounds in some states for special interest groups and partisan politics. As noted by Scott Greytak from Justice at Stake, increased spending in retention elections "puts new pressures on judges who had previously been largely insulated from politicized judicial elections." 29

In highly publicized accounts, Justices have been unseated for making unpopular decisions. In 1986, three California Supreme Court Justices, including Chief Justice Rose Bird, lost their retention elections in the face of a campaign primarily organized around their opposition to the death penalty and the California Governor's criticism of Chief Justice Bird as anti-business. ${ }^{30}$ Ten years later, Justice Penny White lost her retention election in Tennessee because the Tennessee Supreme Court unanimously upheld a murder conviction but overturned the death sentence and remanded for a new sentencing hearing. ${ }^{31}$ In a 2004 partisan election, Justice Warren McGraw lost his bid to remain on the West Virginia Supreme Court after a large coal company CEO launched a $\$ 3$ million campaign to defeat McGraw because of past votes favoring plaintiffs. ${ }^{32}$ McGraw's defeat was partially due to an unpopular vote he cast in a criminal case. ${ }^{33}$ And in 2010, three Iowa Supreme Court Justices lost their retention elections following a successful campaign against them funded by those opposed to the Court's unanimous 2009 ruling in favor of same-sex marriage equality. ${ }^{34}$

These examples represent a miniscule percentage of re-selection events held over the same time period and can be overlooked as aberrant. But have they planted seeds of concern in Justices' minds that sprout when potentially

25. Dark money is often described as campaign contributions provided by "people who want to influence elections without identifying themselves." Danny Emmer, Shedding Light on "Dark Money": The Heightened Risk of Foreign Influence Post-Citizens United, 20 Sw. J. INT’L L. 381, 394 (2014).

26. KowAL, supra note 23, at 4.

27. Id. at 9 .

28. Scott Greytak et al., Bankrolling the Bench: The New Politics of JUdiCIAL ELECTIONS 2013 14, at 2 (Laurie Kinney ed., 2015), https://www.brennancenter.org/ sites/default/files/publications/The_New_Politics_of_Judicial_Election_2013_2014.pdf

[https://perma.cc/N2GM-SD5N].

29. Id. at 4.

30. KOWAL, supra note 23, at 10.

31. Id.

32. Charles Gardner Geyh, Judicial Selection Reconsidered: A Plea for Radical Moderation, 35 HARV. J. L. \& PUB. POL'Y 623, 63132 (2012).

33. Id. at 631 .

34. KOWAL, supra note 23 , at 12. 
unpopular decisions loom? After Justice White's defeat, Tennessee Governor Don Sundquist suggested it should, commenting: "Should a judge look over his shoulder to the next election in determining how to rule on a case? I hope so. I hope so." ${ }^{35}$

In the wake of losing his retention election in 1986, former California Supreme Court Associate Justice Joseph R. Grodin wrote that the election rhetoric, which criticized the Justices' votes on death penalty cases, sent a message to judges that if they want to keep their jobs, they should decide cases according to popular view. ${ }^{36}$ Grodin cautioned as follows:

The risk that judges will receive and act upon that message, unconsciously if not consciously, is substantial. Justice Otto Kaus, my former colleague on the California Supreme Court, has candidly stated in public that he cannot be sure whether his vote on an important case in 1982 may have been influenced subconsciously by his awareness that the outcome could affect his chances in the retention election being conducted that year. I would have to say that the same is true of my votes in critical cases during 1986; I just can't be sure. ${ }^{37}$

In short, pressure on state Supreme Court Justices has ratcheted up in recent years. Scholarship, largely focused on the United States Supreme Court, has suggested that Justices are strategic actors who are influenced in their decisions by internal and external factors. ${ }^{38}$ States must confront whether their methods for re-selecting Supreme Court Justices, with the associated threat of being unseated for making unpopular decisions, serve as external influences on the Justices' independence in decision making.

\section{IV}

\section{FINDINGS AND ANALYSIS}

My hypothesis is: the re-selection methods-elections and reappointmentsimposed on most state Supreme Court Justices tempt them to act strategically to maximize their prospects of maintaining their positions.

\section{A. The Interviews}

To examine whether and to what extent re-selection events affect sitting state Supreme Court Justices in decision-making, I turned to the source: sitting Justices. As one myself, I hoped I would enjoy sufficient credibility that Justices would feel comfortable having candid discussions. Overwhelmingly, that appeared to be the case. Still, as scholars have warned, although stories are a valuable insight into how people think about a topic, they might not tell us how

35. Id. at 10 .

36. Grodin, supra note 3, at 1980.

37. Id.

38. As explained by Epstein and Knight: "[J]ustices may be primarily seekers of legal policy, but they are not unconstrained actors who make decisions based only on their own ideological attitudes. Rather, Justices are strategic actors who realize that their ability to achieve their goals depends on a consideration of the preferences of other actors, the choices they expect others to make, and the institutional context in which they act." LEE EPSTEIN \& JACK KNIGHT, THE CHOICES JUSTICES MAKE 10 (1998). 
those people act. ${ }^{39}$ Caution is also warranted as the interviewer-me-is a peer of the Justices interviewed and is therefore inherently biased. Thus, despite my best efforts to be objective, my observations may be colored by my own views.

\section{Methodology}

There are 351 state Supreme Court Justices..$^{40}$ I sought to interview at least ten percent culled from diverse re-selection systems, different areas of the United States, and from states with both large and small populations. I interviewed thirty-seven sitting Justices (10.5\% of currently serving Justices) and seven former Justices, one of whom was also retired from a federal court bench, from twenty-five states. Twenty Justices are from states with partisan or non-partisan elections, eighteen are from states with retention elections or retention by a government authority, and two are from states with no re-selection processes. To gain a slightly different perspective, I also interviewed four sitting federal judges who formerly served as state court judges or Justices. ${ }^{41}$

I identified who to contact for an interview in a few ways. I initially contacted and interviewed Justices I know. During some of those interviews, Justices volunteered to contact others on my behalf. I also emailed Justices randomly asking for interviews. One Justice contacted me after hearing I had interviewed his colleague. My initial contact with all of the Justices was through an email explaining my research topic, asking for an interview, and promising confidentiality. I contacted seventy-two Justices/federal judges and interviewed forty-four, meaning $61 \%$ agreed to an interview. Two others expressed interest in being interviewed, but we were unable to schedule a convenient time; another Justice sent me an email explaining her views on my topic. The rest either politely declined or did not respond.

Most interviews were telephonic but a few took place in person. After reiterating my thesis topic and the confidential nature of any comments, I asked the same questions of all Justices, with slight alterations due to differences in reselection systems. I also posed somewhat different questions to the federal judges. And sometimes the answers prompted follow-up questions. The interviews ranged from twenty to ninety minutes, with most lasting around thirty minutes. I did not record the interviews but simultaneously took notes, meaning some of my quotes might be imperfect but not substantively so.

Nearly all the Justices and judges were comfortable and forthcoming, more so as the interviews progressed. A significant number expressed relief when I

39. Tracey E. George, Mitu Gulati, \& Ann C. MCGinley, The New Old Legal Realism 18 (2011) (Scholarly Works Paper), http://scholars.law.unlv.edu/facpub/173 [https://perma.cc/KS7YFKL2] (published with changes as Tracey E. George, Mitu Gulati, \& Ann C. McGinley, The New Old Legal Realism 105 Nw. U. L. REV. 689 (2011).

40. District of Columbia Court of Appeals, BALLOTPEDIA, https://ballotpedia.org/District_of_ Columbia_Court_of_Appeals [https://perma.cc/Z4EQ-CFMV] (last visited September 22, 2018); State Supreme Courts, BALLOTPEDIA, https://ballotpedia.org/State_supreme_courts [https://perma.cc/QE4UT2JJ] (last visited Sept. 22, 2018).

41. I obtained IRB approval for all interviews. 
emphasized that I would not identify them by name or court or report any facts that would identify their courts. ${ }^{42}$ They put their trust in my promise, to my great appreciation, which likely increased their candor. The Justices based their opinions on both their own experiences and on conversations with colleagues and peers in other states. As I report below, some common themes emerged.

\section{Common Themes}

Although each Justice expressed his own opinion about the influence of reselection events on deciding cases, some common themes emerged.

a. Re-selection pressures exist but don't typically affect how Justices vote in cases. All justices were initially asked whether the prospect of a Justice losing a re-selection bid impacts decision making. Most Justices said no but recognized that Justices facing re-selection naturally worry about being unseated. As one Justice observed, the influence of elections on state Supreme Court Justices is "subtle" as "no one is going to say, 'if I rule one way I won't be reelected.' But in private conversations, judges will express concern about being reelected." Another Justice in a retention state said that "Justices feel safe until shortly before the retention ... [ $\mathrm{t}$ ]hen anxiety sets in and you start to worry about a number of things including retention." Indeed, almost all Justices in their last terms and retired Justices reported feeling worry-free after their last re-selection event ("I heaved a sigh of relief;" "It takes the load off when deciding high-profile cases"). But does this anxiety affect votes? "I've never seen it," said one Justice, summing up the majority view.

Several Justices accepted that re-selection pressures are simply part of the job and must therefore be taken in stride. As one put it, "[p]olitics are so nasty, dirty, awful, that if someone wants to find a decision to use against you in an election, they will. So don't worry about it." A Justice in a partisan-election state acknowledged that he thinks about how a decision will impact his constituents but has not voted on a case to further his constituents' interests. This sentiment was echoed by a Justice in a retention-election state: "We've had two contentious retention elections here [centered on the Justices' ideology]. It hasn't changed our thinking about decisions, but it has caused concerns about the future."

Some Justices gave examples of the types of pressures brought to bear. One Justice in a retention-election state related that after his Court decided a case against the Governor who had appointed him and another colleague, the Governor's office contacted them to convey disappointment with the decision. The Justice "thought this was highly inappropriate." Another Justice recalled that concerns about re-selection entered his mind when legislators on one side of a case came as a group to sit in the front row of oral argument and stare at the

42. For ease of reading, and to protect confidentiality, I use masculine pronouns when referring to the Justices regardless of their gender. And unless otherwise noted, I include the federal judges in the term "Justices." 
Court, although he was more concerned with how the outcome would affect court funding.

A minority of Justices admitted that the prospect of being re-selected affects votes in cases. One Justice explained:

I have been surprised by that revelation. I have been surprised by some of the language used by my colleagues when discussing how the outcome of the decision would impact elections and how that's part of their consideration in making decisions. I researched the issue independently because I wondered about it and was and am concerned.

A Justice in another partisan-election state who does not plan to seek reelection elaborated:

I think it's always in the Justice's mind. You can't take politics out of anything whether you get to the court through election or appointment, and it depends on the politics of the state and how Justices are selected. . . . I'm mindful of the groups of people who supported me and the people who are in my district. I feel I'm as pure as anyone because I was supported by everyone with no opposition. But still, I am mindful of politics. I want to know how the decision is going to make the court and judiciary as a whole look; how does the decision square with my philosophy and what I ran on? I'm a Republican and I can issue the most liberal decisions and have no consequence. But I won't. If someone says politics don't enter into it, they're lying.

One Justice didn't hesitate to say, "you bet" re-selection makes a difference and "[a]lmost everyone is in denial about it."

No Justice said he had ever voted on a case in a way to appease the public. But even among the Justices who had never seen others do so, many believed it has happened. One Justice's answer to the question of whether re-selection events affect decision making typified others:

I think it can and it has and it will. It doesn't impact as often as people think. I see a lot of judicial independence and courage on the part of Justices here. There's been a few times, less than five times, I stopped and thought "this is going to come back and haunt me," but it didn't change my decision.

Another Justice remarked that re-selection concerns "shouldn't" impact decision making, "[b]ut human nature being what it is, it probably flits though Justices' minds, particularly in big cases and in ones with publicity. But for Justices trying to be neutral and impartial, it's recognized but shouldn't impact decision making."

Some Justices said the impact of re-selection pressures depends on a state's re-selection method. One Justice in a retention-election state remarked:

Based on my discussions with other Justices from other states, I think [partisan and nonpartisan] elections can definitely shape their decisions. In Michigan, Illinois, and Wisconsin, opposition groups will use Justices' opinions to go after them. This is much less likely in a retention election unless there is a high profile controversial case like same-sex marriage out there.

The Justices sitting in states with no re-selection methods took a "grass is always browner" view of the pressures put on Justices in other states. As one answered when asked whether the decision-making process for Justices on his court would be different if they had to stand for retention or re-election:

I don't see how it could be otherwise, I really don't. That's the problem with elections. There is an inherent coercive effect; you're always looking over your shoulder wanting to get elected or re-elected. It you write opinions that the public doesn't agree with, it 
affects you. We've had to write controversial decisions, and if I had to worry about reelection, it would have been awful. If I had to worry about being vilified by an opposing party, it would have been awful. It's freeing being able to decide these matters without the personal worry.

A few Justices related that concerns about re-selection have impacted votes on whether to grant discretionary review in a case. One explained:

I don't think it [re-selection concerns] impact our actual decisions because we rise above it. But are we concerned about that when deciding whether to grant review? Maybe. I can't say we don't consider it. If it's something controversial like same-sex marriage, we might want to deny review or decide [the case] on a procedural issue to avoid deciding the merits. We try to avoid the issue sometimes.

Another Justice said he has "heard people say, 'why grant review when all this is going to do is anger the legislature or people?' It's made me mildly uncomfortable that this was a consideration."

The federal judges likewise expressed concern about the impact of reselection events. When asked whether he felt less constrained in making decisions now compared to when he served in the state court system, one federal district court judge responded: "Absolutely. I get a whole lot more press now, so everything I do is subject to much more coverage. But I recall when I transferred over here, I remember feeling relieved. And I didn't even realize I had felt constrained. But I did." He related that he could not have handled a contentious case involving a popular politician the same way had he been a state court judge. "A state court judge would have been run from office, probably, with [the politician's] supporters and war chest. I got calls from people saying, "just wait for the election,' not realizing they couldn't affect me." All the other federal judges echoed this expression of relief from worry over re-selection. As one said, in making decisions now, "[t]here isn't in the background the possibility of losing your job."

b. Justices combat pressures attendant to controversial cases by tapping a deep-seeded drive to "do the right thing." The question I posed that prompted the most thoughtful answers was whether the Justices considered how the outcome of a controversial case might affect their chances for re-selection and, if so, how they dealt with it.

Most Justices said they were acutely aware of the controversial nature of pending decisions. "It has to be a consideration; it has to enter your mind. I am aware of media and social media," said one Justice, echoing others' comments. Another noted, "I'm not oblivious to it. One can't close their mind to knowing that a decision will help or hurt in the re-election effort."

But others did report being oblivious to controversy. "Ninety-nine percent of the time, I never thought what I was doing was controversial," said one Justice, "so I can't take credit for being brave as I thought I was being logical." Another Justice sheepishly chalked up his obliviousness to egotism: "I was fairly arrogant in that respect. I assumed that my decisions would be met with general approbation." And one Justice expressed surprise about the public's negative reaction to his Court's decision in a social-issue case: "I don't remember 
consciously thing about it. It floated through my mind that people would be unhappy. I followed the law, the [issue] was clear cut, and we never talked about it being a problem for the [election]."

Many Justices remarked they never considered how an unpopular vote might affect them, but others recognized the threat and disregarded it or embraced it. One Justice said, "You do think about it, but there is nothing wrong with that. It makes you more scholarly [in your decisions]." To deal with perceived public pressure, these Justices spoke sincerely, and often passionately, about their desires to preserve the independence of the judiciary by ignoring personal concerns. No one thought their actions extraordinary, just necessary for the greater good. These comments by various Justices are emblematic:

I was stubborn and wouldn't cave into public pressure. I knew I could make a living as a trial attorney. Being idealistic in the sense of wanting to do the right thing isn't being brave. It's not the same thing as being in Nazi Germany and facing being shot for not following the regime's view; I'm not sure I could do that. In the end, my refusal to yield to public pressure is a combination of wanting to do the right thing and being rebellious.

…

It's inconsistent with my job to be guided by [re-selection pressures]. I believe that being independent is the most important thing to being a judge. If I wasn't, I feel I would let all judges down.

$\ldots$

I deal with it with courage. I push it out of my mind. In part, too, because all judges have faced it. We get strength from each other.

...

I just remember my oath to steer clear of any influence. I do what I need to do and think that even if I write something benign, someone can use that against me in the current media market. Detractors can pull one quote or holding out of context and use it against me. The majority of people voting won't read my opinions. It's the lawyers and the judges below. I just try to be out there and let people know me and don't worry about what's said.

$\ldots$

My grandma used to say you can't keep birds from flying overhead but you can keep them from nesting in your hair.

Many Justices also said they accepted that they could lose their jobs for making an unpopular decision but reassured themselves with the knowledge that they could make a living elsewhere. One Justice shared his pragmatic view:

How do I deal with the knowledge that I'm up for retention next year? I think, "what's the worst that can happen?" I had a good run and I'll go back to practice. And I can look myself in the mirror. Not even a close call. I would rather go down being true to myself and my profession than stay here and manufacture a position for fear of being thrown out.

Justices also described what it was like to be challenged in re-selection events and how those experiences affected them. One Justice recalled a challenge early in his judicial career:

[A colleague] wrote [a controversial social issue] decision and I joined. The Republican Party came after us both. I raised money just from family and friends. Very tough. When I signed off on the case, I didn't consider the consequences. I had to travel all over the state and interview with newspapers. So many people stepped up because they wanted 
to preserve judicial independence. It was a distraction from my duties, but it was nice to meet people and it was good to preserve the system. I wouldn't want to do it again, though! I was [easily retained]. In the next election, I did nothing to campaign and was retained with no problem.

Another recounted being targeted by an outside group during his re-selection bid:

A group went after me . . based on a dissent in a case concerning . . . [a law about monitoring] sex offenders. I had written ... that the new law was [unconstitutional]. The group ran attack ads that played constantly, showing children on a playground and saying 'Justice $[\mathrm{X}]$ sides with child molesters.' It was funded by dark money. The ad was so over the top that people were outraged. I was interviewed by the media about it a half-dozen times. I won by the largest margin I had ever had. ... Despite this experience, I don't do things differently. I thought before my first election that you just have to be an independent decision maker. If you're doing your job, there's something there for everyone to hate you, so you can't worry about it.... One of the unfortunate impacts from that election is that a lot of people have told me that they have thought of running for the Court or other courts, but they changed their minds after watching what I went through.

Some Justices discussed the impact of prior challenges to their colleagues' reselection bids. Most of these Justices recognized that the prior challenges were aberrant events that were not predictive, and if anything, these events, although worrisome, caused these Justices to double down on their resolve to block out any considerations of personal imperilment when deciding controversial cases.

c. Re-selection does not generally affect how decisions are written. When asked whether re-selection events impact how opinions are written, about fifty percent of Justices with views on the issue answered no. ${ }^{43}$ One Justice's response typified others: "It's not judicial elections. Is public perception influencing opinions? Yes. We're careful to explain and reduce unnecessary flourishes. No need to use colorful language to provoke. That's why you find more colorful language in dissents." Others echoed this sentiment, emphasizing that they endeavor to avoid offending parties or lower courts and organize high-interest opinions so lay people can readily understand them.

The other half of Justices thought that re-selection affects opinion drafting. Most in this group spoke about clarity and tone. As one thoughtful Justice explained:

I think we alter the writing by softening the language to make it more clearly understood and palatable to the public and our constituents. But there is nothing wrong with that. I want to leave a good legacy, and I want the Court to look great. I will do an additional concurrence to provide more rationale in a softer way when I think the public or media might misunderstand the reasons for the majority. Often, my concurrence might be picked up by the press. Why did I do that? Maybe to make people think I really care about it. I wouldn't do any differently if I was a Federal judge. We need to make sure that the public has faith in the judiciary.

Some in this group also spoke to the need to handle high public interest cases with care. "With hot button cases, I want to acknowledge the [legitimacy of] the

43. Four Justices were unsure whether re-selection impacts opinion writing, and two Justices expressed no opinion. 
other side," explained one Justice. So, for example, in overturning a death sentence, he is more likely to appease victims by saying something like, "the Court does not take this action lightly." One Justice candidly acknowledged that some decisions issued from his Court are written in a way to maximize a Justice's chances for re-selection:

Some of what is written is written with the next election in mind, particularly in death penalty cases. One member [of my Court] is always intent on writing on death penalty cases as more of a political statement. ... As the election year draws near, his writing becomes more rabid.

He added that "sometimes we can take an issue and something can be written more broadly and should be, but instead it's very, very narrowly tailored to be confined to just one case" for fear of public reaction.

Language in dissents is sometimes included solely to appease Justices' supporters. These Justices "'wave the bloody flag,' meaning they play to their group," said one Justice of a few colleagues, "for example decrying that the majority has made a threat to democracy. It's playing to your base. Whether done consciously for the election, I'm not sure. It's just saying to the base, 'we're still on your side." 'Another Justice also noted that Justices will occasionally insert "disclaimers" about whether a result reflects a good or bad policy, especially when upholding legislation.

Surprisingly, more than one Justice said that re-selection concerns can muddy opinion drafting. One observed that "if the majority wishes to yield to the public view, the decision is typically poorly written and conclusory. It avoids directly taking on precedent that challenges the decision's outcome. It just declares the result." A scholarly Justice who had clearly thought about the issue pointed to Professor and former Arkansas Supreme Court Justice Robert A. Leflar's article, "Honest Judicial Opinions," ${ }^{44}$ as evidence that Justices may mask their decisions with vague language. The interviewed Justice thought this masking may possibly be in reaction to re-selection concerns. One Justice expressed more outrage:

It's a reality that politics play a role in the judiciary when Justices are elected. . . I've been amazed at some of the antics in drafting and crafting the opinion to support [a politically popular result]. It goes on during the election seasons and in high profile cases like when the governor sues the legislature for $\mathrm{X}$ power.

One Justice thought that the judicial evaluation process in his state, which goes hand-in-hand with re-selection, along with the desire to be good jurists, compels Justices to craft better decisions. "We always understand we'll be evaluated on the quality of the reasoning [and] writing" in a decision, and "we do take that seriously ... The desire to be a good judge is reinforced by the evaluation system."

d. Re-Selection does not generally tempt Justices to recuse from controversial cases. I asked whether the Justices ever suspected that a colleague had recused from a controversial case to avoid deciding it before an election.

44. Robert A. Leflar, Honest Judicial Opinions, 74 Nw. U. L. REV. 721, 741 (1979). 
Overwhelmingly, the answer was no. But seven Justices answered yes. In one instance, a Justice was suspicious because, "the decision wouldn't have gone over well in the recusing Justice's district." Another Justice was more than suspicious when a colleague running in a hotly contested partisan re-election bid recused in many cases and sometimes announced ridiculous reasons for doing so.

Of note, one Justice remarked that "the greater infraction is not recusing when you should," stating his belief that some Justices on his Court should have recused from a case when seeking re-selection to avoid the perception of impropriety.

Interestingly, some Justices reported that recusal is much more of an issue with judges on lower courts. As one put it, "[r]ecusals are disfavored at the Supreme Court because it has to be explained," but "I have seen it at the trial level on occasion." Three Justices said that some of those judges have reportedly recused to avoid deciding controversial cases when they were seeking appointment to either the intermediate courts of appeal or the Supreme Court. One Justice said that while he was on an intermediate appellate court, "I saw people constantly getting off high profile cases" and noted that this was "a pattern with people applying for this Court." Another Justice, who had once served on an intermediate appellate court, volunteered that successive chief judges knew when people were up for re-selection and purposefully avoided assigning controversial cases to those judges' panels.

e. Justices do not generally avoid authoring dissents to strategically protect against being singled out for possible electoral sanction. In the mid-1980s, Melinda Gann Hall argued that the low dissent rate in state Supreme Courts could be explained, in part, by Justices using a strategy of not dissenting in cases of high public visibility to avoid being singled out for "possible electoral sanction." 45 She theorized as follows:

For judges, controversial decisions become more difficult to justify on the basis of law when they depart from the majority's decisions and vote in the minority. It can be argued that though voters may accept a legal explanation for a unanimous court's unpopular decision, the mechanism of judicial accountability is more rigidly adhered to on issues where voters have information and strong preferences and where judges have singled themselves out for criticism.

Therefore it can be hypothesized that justices who strongly desire re-election and fear the possibility of electoral sanction will not distinguish themselves from the rest of the court by dissenting on highly salient political questions. Instead, a justice will either vote with the majority or will mask his or her disagreement in a concurrence rather than a dissent. In other words, we should see a higher level of unanimous voting relative to an overall pattern on controversial, very visible issues for certain types of justices. ${ }^{46}$

To test her theory, Hall conducted in-depth, confidential interviews with each Justice sitting on the Louisiana Supreme Court in 1983. Justice "A" told Hall that although he "professed a personal abhorrence of executions and the death

45. Melinda Gann Hall, Constituent Influence in State Supreme Courts: Conceptual Notes and a Case Study, 49 THE J. POL. 1117 (1987).

46. Id. at 1119. 
penalty," because his constituents supported capital punishment and would retaliate against him at the polls for taking a contrary view, he did not dissent in cases affirming a defendant's death sentence ${ }^{47}$ Indeed, although Justice "A" filed dissents in favor of criminal defendants' claims in $26.0 \%$ of non-capital cases decided in a single term, he dissented in favor of criminal defendants' claims in only $3.3 \%$ of capital cases decided that term. ${ }^{48}$

I related Hall's findings to the Justices I interviewed and asked whether they had seen evidence that Justices avoided being singled out in controversial dissents to maximize job security. The majority answered no. A few took issue with application today of Hall's theory. As one Justice said: "With controversial cases, if we have sharply different views, we're more likely to write separately." Another Justice expressed a similar sentiment: "I've stuck my neck out and so have my colleagues. We try to find consensus where we can on high profile cases but we have no qualms about dissenting. But we try to bring folks on board." Still another said: "I wrote a dissent in a case concerning the Governor's desire to put something on the ballot... The majority allowed it, but I was the lone dissenter. I didn't care about going against the grain."

Some Justices discussed other reasons for not dissenting even when a Justice disagrees with the majority opinion. "In writing a dissent, a Justice has to pick his battles. I don't see people doing that for political reasons," said one Justice, while another pointed out that " $[t]$ here is no point in dissenting when doing so wouldn't make a difference." Another Justice addressed the costs of dissenting:

Stronger forces militate low dissent rates. Primarily, the culture of the court. Internally, we are collegial and get along. Being a frequent dissenter carries other costs. It identifies you as someone not effective at getting others to agree with you. Dissention is a concession of defeat. We're always faced with the quandary of trying to join the majority and trying to make it better or exiting and dissenting.

Conversely, a Justice explained an incentive to try and reach consensus: "Part of the calculus is wanting to be part of the majority to temper it." And another noted that when the opinion is taking a view contrary to public consensus, "[w]e try to be as strong as possible to present a united front."

One Justice had a unique, and disturbing, explanation for what dissuades some Justices from dissenting:

A bigger problem is that there are some Justices who are perceived as persuasive among the public and the legislature. They have pull. So, it's more convenient and expected to side with whatever the position is taken by those Justices even if justice says otherwise. And if you're up [for re-election] soon and need help from those Justices, you're likely under pressure to agree. The reason is that this Justice can help with grassroots support and getting legislative support. Statewide elections are expensive. If Justices have that kind of pull, the inclination is to vote with them even when the Justice's personal inclination is otherwise.

Another Justice mentioned that his dissent rate was used against him in his re-election bid. "When I was attacked in the election, [my opponent] said I was

47. Id. at 1120 .

48. Id. at 1122 . 
an outlier and he counted the dissents and tried to use it against me. He also tried to use it to show I wasn't liked by the Court."

Several Justices reported evidence supporting Hall's theory. Most of these Justices reported conversations had with Justices from other Courts. One Justice said:

I've attended national events. In private discussion with other judges, some who are elected are very concerned about voter reaction. I remember one judge saying that if a dissent wouldn't matter, why bother dissenting if it would only impact re-election chances. That makes me glad that [my state] doesn't have partisan elections.

Another Justice had a similar experience, observing that "[c]ourt culture varies. A judge from another state once candidly told me that he had to decide a case a certain way because he had an election coming up. I was shocked."

Some Justices reported first-hand experiences that supported Hall's theory. One Justice complained that the electoral process "incentivizes Justices to refrain from expressing an unpopular opinion." He resists this temptation:

I try to write dissents/concurrences all the time if warranted. I do know that some colleagues feel differently because they don't want to highlight that the majority thinks their position defective. I don't feel that way. If people want to judge me, I want them to judge me on what I decide. I'm not enthusiastic about consensus. I won't dissent just to embarrass someone, but I will if I feel strongly on an issue.

f. Courts rarely delay the release of opinions preceding an election. Most Justices reported that they had not seen a controversial opinion's release delayed in the weeks before an election. But several Justices recalled instances when this occurred. Some Courts openly discussed the practice. "I don't remember which [case, but] I remember discussions about the appropriateness of releasing an opinion before an election," remarked one Justice. Another Justice stated that "I've seen people hold them and, at least twice, the Justices were candid in saying that the case is controversial, and the Justice is going to hold it until after the election." This practice is justified, explained a Justice, to "avoid releasing cases that would cast a Justice up for retention in a bad light." Another Court discussed the matter and held a "number of cases" before an election over the objection of one of the Justices I interviewed.

In other Courts, the practice of delaying opinion releases is not discussed but sometimes occurs at the authoring Justice's behest. And a few Justices said they had suspected that a colleague sat on a case to avoid releasing it before an election. "I've noted a time or two that the case is held a little bit longer than necessary," commented a Justice, who echoed others. One Justice reported observing more blatant displays:

I see decisions get right to the point of issuance and then pulled from the [release list] because an election is impending. I've also seen how an individual on the Court seeking a federal appointment handled a controversial case. The decision was ready to go, but all of a sudden he pulled it from the [list] to "study it." It's still being studied and he's awaiting the outcome of the appointment.

A few Justices reported knowing that decisions were delayed in lower courts. One Justice said that a trial court judge he knew continued sentencing in a death penalty case past an election date. After that judge was re-elected, he imposed a 
non-death sentence, which caused a "hue and cry" among his constituents. Interestingly, the Justice also knew of a court of appeals judge who timed releases of controversial opinions for days least likely to garner press coverage.

g. Justices are divided on what the best methods are for their selection and re-selection. Reminiscent of the historical fluctuations in opinion about the best way to select and re-select state court judges, no consensus emerged from the Justices on this topic. Unsurprisingly, most Justices favored their own systems and pointed out flaws in other states' methods.

Justices in retention/re-appointment states questioned the wisdom of permitting voters to select judges. One Justice viewed voters as unqualified to make these decisions:

\section{Notwithstanding that Jefferson railed against the provision that provided for lifetime appointments, if he was alive today, he would disagree with this former stance. Electing judges is the worst idea. Lay people aren't qualified to decide if judicial candidates are qualified. And they have no real undersetting that most laws protecting rights, most notably state and federal bill of rights, are designed to be counter-majoritarian. And that's antithetical to the notion that it's a good idea to elect judges.}

Justices in this group more frequently lamented the campaign fundraising attendant to partisan and non-partisan elections. A Justice who had formerly run in partisan elections as a trial court judge commented, "I know from experience that the people who want to give money are lawyers and corporate entities. So that's the danger. You have to raise big bucks to run." Other Justices questioned the independence of Justices in states with partisan and non-partisan elections. One recalled his experiences as a trial lawyer practicing in multiple jurisdictions:

$[\mathrm{M}] \mathrm{y}$ track record with partisan-elected judges was worse than with retention-election judges. I think there was a bit of "pay to play." I walked into one courtroom in Texas and all the attorneys were talking about whether they were current in their contributions to the judge. The judge was not in the courtroom. Things did not go well for me.

One Justice's experience as a lawyer litigating a series of education-issue cases before another state's Supreme Court during an election year made him a lifelong advocate of merit selection:

We went to the [state] supreme court [multiple] times. We watched the results carefully and actively encouraged people to make contributions to the candidate that favored our position. All the decisions in our cases were [close calls] and a change of one Justice would have made a difference. There was absolutely no question that the election would decide our case. [The Justices we backed] won and we won. I have become such a militant about merit selection as a result.

Retention-election states were also criticized for the potential influence of funded campaigns. Justices from those states that have not had challenges mounted against sitting colleagues nevertheless expressed concern about future challenges. "In [my state], we've been lucky by not having high-dollar campaigns against anyone [standing for retention]," remarked one Justice, but he worried how such challenges would impact his Court. "I would hope Justices would [still] call them like they see them." Regardless of the possibilities of challenges, most 
Justices in retention states don't mount campaigns. This Justice's laissez-faire attitude was typical:

One Justice told me [in the year of my retention bid] that I should do nothing because there is nothing to do. [My state] is a huge state, so what am I going to productively do? I could spend a lot of time raising \$1 million, but that won't go far. And who is going to raise money to beat me? And to what end? Just to appoint someone else like me? Structural factors militate against a Justice making any effort in a re-election unless he hears of a campaign.

Justices in retention-election states generally opined that retention elections strike the right balance because they permit people to have some voice in judicial re-selection and take political pressure off the judicial system. "Having a retention election, merit system, is a liberating factor," said one Justice, "you don't have to worry about how a decision impacts you personally. I would like to hope that Justices in partisan election states don't worry about it, but that would be naïve." Another Justice agreed, saying that "[m]erit selection for the most part eliminates" the concern about elections influencing decisions. He acknowledged that "our system, although not perfect, avoids some of the pitfalls that elected systems have."

Justices in partisan and non-partisan election states acknowledged that some influences exist due to elections. One Justice noted, "Does the Court change during an election year? Yes." Another Justice said about the impact of elections:

I've heard other judges and Justices say, "I can't do that because an election is coming up" and that's frightening to me. It's alarming and I respond that people would respect the integrity behind the decision even if they disagree with the result. I also ask them whether, regardless, they feel they have an obligation to do what they think is right. The prevailing answer is "but I have to think about my own election." I've heard this from judges and Justices in other states as well.

This sentiment was echoed by other Justices. "One Justice [on my Court] has said that my constituents want me to vote for it, so that's the second reason for voting for it," related a Justice. A Justice in a partisan-election state related that a trial court judge recently called him upset about the "overwhelming" backlash he got from his supporters for holding a police officer in contempt because they thought it would hurt his re-election chances. "[That judge's] circumstance is typical."Another Justice in the elected-Justices group was most concerned with public perception:

I think there are virtues with electing Justices. But the problem with elections is (a) Justices actually adjusting a decision to satisfy the electorate or contributors, and (b) a perception that this is what occurs. And there are concerns about where the campaign contributions come from. I'm more certain that the appearance problem is the real concern.... When there is a decision with political impact, the media reports the party affiliation of the Justices. For example, they say "three Republicans voted one way and four Democrats voted the other," which perpetuates the perception that party affiliation drives the decision.

But many Justices in partisan and non-partisan election states touted popular elections over retention and re-appointment systems. One Justice in a nonpartisan election state decried the "political litmus test" that exists when a Justice is appointed. He was once asked by his state governor whether the latter's 
vacancy-filling appointments to the appellate courts needed to be more balanced. The Justice candidly told the governor, "yes." He elaborated:

Ninety percent of appellate judges here start with an appointment. . . In my state ... one [political] party has run the table for so long. Almost all the political weight is behind the scenes in the appointment selection process. You just know that the governor will select someone who is passionate about how to decide things a particular way. Governors appoint "fellow travelers" and judges are in denial about how objective they are.... Some Justices on the Court wouldn't have been appointed by a governor because they are independent in their decisions. But they're on because they won an election.

Others were likewise concerned with being beholden to an appointing authority. "The initial reaction of a new Justice is to stay close to the ideology of the appointing authority," observed one Justice when discussing his Court's midterm appointees. "Maybe the further the Justice gets in time from the appointment, he or she might go away from that. People do that. When the Justice gains a sense of independence from the executive branch, he or she is more likely to decide the case only on the law." Two Justices drew on their own experience to emphasize this point. The first recounted:

Having been through two elections and one appointment, I found the appointment process just as political but behind closed doors. You would never be appointed in [my state] if [you are a member of] a different party from the governor. The voters are more engaged and wanting to know about the candidate and that's more refreshing.... Since Citizens United, there are more opportunities for outside groups to influence the election. Scary. But they influence the appointment process, too. The voters, like juries, do the right thing.

And the second Justice concurred:

I wouldn't want a lifetime appointment. I don't believe in appointments. I've been elected [multiple] times and through the appointment process [multiple] times. There are more politics in the appointment process. Only the governor appoints with no citizen nominating commission. . . . I'm not fond of the appointment process. ... I also don't like retention because both sides might want to vote you out. I would rather have a flesh and blood opponent.

Many Justices in this group also applauded that elected Justices are more accountable to and in touch with the public. These comments are representative:

I think state court judges are also people who are active and known in their respective districts and counties. I'm not a fan of our current U.S. Supreme Court because they're out of touch.

$\ldots$

I have to raise money here, and I don't like it, but I do the best I can to do it right. The good things about the electoral process is that I have to go among the people of the state, I have to hear about what people are concerned with-not in the sense of casting votes. People want judges who are honorable and run a system that keeps them safe. The thought that a judge can ignore sentiments, the opinions of the public, that's not a good thing. It's healthy to have honorable judges, raising money appropriately, and deciding cases responsibly.

…

My observation is that some of the most politically unpopular and arguably wrong decisions have been made by unelected judges, primarily federal judges. Without some type of accountability, some of these judges feel empowered, apparently, to do what they want. 
Unique in his comment, one Justice welcomed the prospect of an ineffective colleague being given the boot by voters:

With elections, there's some accountability. It might not necessarily be better. . . Sometimes I saw Justices that I was glad would probably only serve one term. There are lots of problems with lifetime appointment. . If perfect people were in the job with a lifetime appointment, it would probably be great. But that's not going to happen.

And at least one Justice didn't blink about being affiliated with a political party. "Shouldn't the public know about candidates? Isn't there a benefit to people to know about political affiliation?" he inquired. "It's not a hard and fast way to predict votes, but it's useful information in light of the political decisions sometimes made," he concluded.

Justices from every system reported concerns about the increase of outside funding affecting a Justice's re-selection bid. The combination of Citizens United v. Federal Election Commission ${ }^{49}$ and Arizona Free Enterprise Club's Freedom Club PAC v. Bennett $t^{50}$ has been "problematic," bemoaned a Justice in a partisanelection state. He described the first Supreme Court race in his state after those decisions, wherein a single outside entity raised more than $\$ 3$ million to defeat the candidate whose hands were tied by the public financing system. "After Citizens United, more money poured into [my state's] court races. Despite the group's agenda, they usually pick a hot-button social issue to attack with, usually tarring the Justice by saying he helps criminals. Everyone who runs dreads the prospect of being a target."

Citizens United was brought up several times in the interviews and never in a positive light. A Justice in a sparsely populated state still favored the electoral process but lamented the changes wrought by Citizens United:

The election process has changed here, as it has in other states. The outside groups, because of Citizens United, give independent expenditures. This is a cheap media market and a small state, so a little goes a long way. Advocacy groups . . . have been here for three cycles unsuccessfully. It has changed the election process quite a lot because candidates are now required to raise more money whereas before they didn't. Also, now there are more contested elections.

A Justice in a retention-election state noted a year in which "[t]here was a concerted effort to run off several Supreme Court Justices" by people outside the state. Although the effort was unsuccessful, it lowered the typical retention percentages. "The people behind [the campaign] disappeared." Another Justice lamented the difficulty of raising money for a retention election when there is no opponent, making it more difficult to counter challenges.

Despite the pitfalls of each type of selection and re-selection system, most Justices did not think their Courts would operate differently if Justices had life tenures. A Justice who later served in the federal judiciary expressed doubt whether the state Supreme Court would change if Justices were given life tenure:

49. 558 U.S. 310 (2010) (lifting restrictions on independent expenditures by organizations communicating about a candidate).

50. 564 U.S. 721 (2011) (striking matching funds provision of state public campaign financing act). 
"I've served with federal judges who still bowed to majority view and didn't want to be considered too liberal or too conservative."

Surprisingly, many Justices did not want life tenure. Most, like this Justice, preferred a system that holds a Justice accountable for his performance:

I think in general terms, we should hold judges accountable for what they do. We want judges who make good decisions on the law, have the ability to write, and who conduct themselves with integrity. We need a system that insures that judges perform how we want them to while minimizing political influence. Justices need to call it like they see it without political factors weighing them down. We need to insulate judges without losing accountability.... There are always folks who might struggle in a particular area. If they are struggling, we need a process to help improvement and then hold these Justices accountable if they don't improve.

Another Justice thought the electoral process improved his judicial performance:

The electoral process is an accountability tool. I wouldn't be here if it didn't exist. I disagreed with the former Chief Justice so I ran against him. My awareness of the other branches' concerns and the community's concerns is broader for running. It means you write a better opinion because you have these concerns in mind. The decision doesn't change, though.

Some Justices also expressed discomfort with unchecked decision-making. For example, one offered his opinion that, "state judges are more reasonable than federal judges, not as pompous. I wouldn't want to become that." Another commented that he sees "activist judges" in the federal courts because they aren't accountable. "Most of us think being closer to the people is good," remarked another. And another believed that lifetime appointments cause federal judges to lose their "filters" and "say whatever pops into their heads."

A few Justices thought that the culture of their Courts might change if they were appointed for life, like federal judges. One Justice said he and his colleagues might be less sensitive or less empathetic and more outspoken like some federal judges, thereby affecting how decisions are written but not how they are decided. A thoughtful Justice supposed that a life tenure would cause the Justices to perceive themselves as more independent. He thought that federal judges know this internally. "It's more talked about in terms of a tradition, i.e., the tradition of the federal judiciary." This unrestrained independence may also exist among Justices serving in their last terms. One such Justice reported that his colleague, also in his last term, commented that "we both have a free shot to do what we want to."

h. Good character is the key characteristic for an independent Justice. Although I did not ask about key characteristics for high-caliber Justices, the topic of character continuously popped up when discussing the pressures placed on Justices by the re-selection process. This Justice's comment echoed others: "It takes character to be a judge. He or she must 'compartmentalize' the outside, personal concerns to make decisions that they might not even like." Another phrased it this way:

If you put honorable people on the court, who understand the rule of law, they would more likely make decisions without considering how it might impact their chances for 
re-election. If you put people of lesser capabilities on the bench, maybe you would get a different result. There is always a temptation to change a bad policy, but we don't have the authority to change it. The answer to the problem is to structure the system of selecting judges in such a way to make sure that the best people available are the ones put on the bench.

A federal judge who used to sit on a state intermediate court of appeals was candid in his views:

I think there is risk that [the possibility of losing a re-selection bid] would impact decision making. It has a lot to do with the integrity of the judge. As a former state court judge, there is no way you can't not think that your job is at issue. It risks affecting the substance of the opinion and definitely does affect the logic of the decision and perhaps its timing of release. The risks are there; it just depends on the integrity of the Justice to do what's right.

Some Justices mentioned other important characteristics for Justices. "The take away," said one Justice, "is that we should always have people on the bench who don't really want the job so much that they'll compromise their views to retain it. The best judges are the ones who know they can make a living elsewhere." Another noted that Justices who view themselves as politicians are more likely to vote in a way to maximize their chances of re-selection. He recalled sitting on an education panel with a judge from another state and thinking, "how can he talk like a politician?"

A few Justices proposed taking the pressure off them by having longer terms. Justices with longer terms uniformly felt less anxious than Justices with shorter terms. "The prospect of losing is so remote, temporally," said one, "that you don't really think about it." But even longer terms don't fully immunize Justices from the anxiety of re-selection. One Justice with a long term related that a colleague is running in a non-partisan election in 2020 "and he is now mentioning it all the time, so he's worried."

\section{B. Empirical Evidence: Dissents and Special Concurrences}

My sub-hypothesis is: the re-selection processes used for sitting state Supreme Court Justices encourage those Justices to act strategically in dissenting and specially concurring to maximize their prospects of maintaining their positions.

There has been an abundance of literature suggesting that elections may influence judicial decision-making, especially in criminal cases. The majority of Justices I interviewed vehemently denied that the prospect of losing their jobs influenced their decisions. But many candidly admitted that they can't help but consider whether some decisions will hurt their chances for being re-selected. Do Justices' personal worries subconsciously impact their decisions?

To answer that question, which would further support or defeat my major hypothesis, I created the above sub-hypothesis. To test it, I examined whether the prospect of losing an upcoming re-selection bid impacts a Justice's decision to dissent or specially concur. The primary reason for a Justice to do so is disagreement with the majority about its conclusion or reasoning. As Hall found, however, some Justices may choose not to dissent when doing so would express 
an unpopular public view and would not affect the case outcome. ${ }^{51}$ And in my interviews some Justices said they sometimes preferred to write separately to more clearly explain decisions to the voting public. If re-selection concerns indeed influence Justices in deciding whether to dissent or specially concur, either consciously or subconsciously, different patterns should be detectable in the years preceding and following a re-selection event.

\section{Methodology}

To determine whether Justices' behaviors in dissenting or specially concurring are influenced by the prospect of a re-selection event, I first identified the Justices who were re-selected in 2014 and served for a full year thereafter. I then excluded Justices appointed less than one year before an election. Sixty-five Justices comprise the group examined.

I chose 2014 for a few reasons. Re-selection events that year occurred after the highly publicized 2010 Iowa retention election in which three Justices on the Iowa Supreme Court lost their seats in the wake of that Court's controversial same-sex marriage opinion. That event sent shockwaves through many meritselection states, where Justices had believed that retention elections were only lost when a Justice suffered some type of personal downfall, like excessive drinking or gambling. Also, by 2014, Justices seeking re-selection were sometimes confronted with well-funded opposition campaigns by groups with agendas, which raised real concerns that Justices could lose their positions for making unpopular decisions. In short, the atmosphere present in the years immediately before and after the 2014 re-selection events are like those that exist today, making the findings more relevant.

I performed Westlaw searches to count the number of dissents/special concurrences authored or joined by the Justices one year before and one year after their re-selection. Partial dissents and partial concurrences were counted as "dissents/special concurrences." I then calculated the percentages of total cases decided in which the Justices dissented/specially concurred in each year and recorded the percentage variances. ${ }^{52}$ I separately recorded variances in dissent/special concurrence rates in criminal cases because "tough on crime" was a common campaign theme in $2014,{ }^{53}$ and criminal cases often grabbed public attention, which may have tempted Justices to treat these cases differently. Juvenile delinquency cases based on criminal acts were included in the criminal case type. Finally, I assigned each Justice a number and identified their method of reselection: partisan election ("PE"), non-partisan election ("NPE"), retention election ("RE"), and re-appointment by a government entity ("REAPPT") to discern the impact of re-selection methods.

Table 1 shows the list of sixty-five Justices, their methods of re-selection, the percentages of cases in which they authored or joined a dissent/special

51. Hall, supra note 45, at 1117.

52. The total cases decided each year excluded cases in which the Justice was recused.

53. GREYTAK, supra note 28, at 3. 
concurrence the year before ("year 1") and the year after ("year 2") re-selection, the percentage variance between the years, and the variance rate for dissents/special concurrences in criminal cases ("CR"). For the Justices serving on Courts that do not hear criminal cases, " $\mathrm{n} / \mathrm{a}$ " is noted in the column recording criminal case variance rates.

Studying the information for Justice 1 aids in reading Table 1 . Justice 1 was re-selected in a partisan election. He dissented/specially concurred in $73.91 \%$ of the cases he decided in the year before his election and did so in $74.28 \%$ of the cases in the year following the election, meaning he dissented/specially concurred $.37 \%$ more in the year following the election. But he dissented/specially concurred $20.56 \%$ fewer times in criminal cases the year following the election.

Tables 2 through 4 isolate the information in Table 1 by method of reselection. Those tables should be read in the same manner as Table 1.

\section{Results and Analysis}

As with many statistical studies, the results should be read keeping in mind that the below-reported variance rates are not based on large numbers. Most of the sixty-five Justices' dissent/special concurrence patterns studied belonged to Courts which decided fewer than 100 cases both the year before and the year after the 2014 re-selection event. And the number of dissents/special concurrences in a studied year ranged from zero to thirty-three. In my experience, these numbers are typical. These relatively low numbers make it difficult to put significant weight on statistical variances in dissent/special concurrence rates. But examining variance rates adds a sliver of light in testing the hypothesis.

Assuming that a $5 \%$ variance in the percentage of dissents/special concurrences written or joined in the years before and after a re-selection event is statistically significant, three conclusions can be drawn from the information set forth in Table 1.

First, although most Justices' dissent/special concurrence patterns for all case types did not vary greatly in the year before and the year after re-selection events, about one-third of the Justices' patterns varied by statistically significant percentages. Twenty-four Justices had a variance equal to or greater than $5 \%$. See Figure $1 .^{54}$ Interestingly, among that group, nineteen Justices dissented/specially concurred in a smaller percentage of cases the year after a reselection event. See Figure 2. This fact confirms Justices' comments in interviews that they were sometimes motivated to write separately to better explain their decisions to the voting public or others responsible for their re-appointment.

54. Figure 1 shows the percentage variances for all case types from the year before a re-selection event and the year after. Positive numbers indicate that a greater percentage of dissents/special concurrences were filed the year after a re-selection event and negative numbers indicate that a smaller percentage were filed in the year after a re-selection event. Figures 2-10 should be interpreted in the same manner. 
Figure 1: Percentage variances for all case types

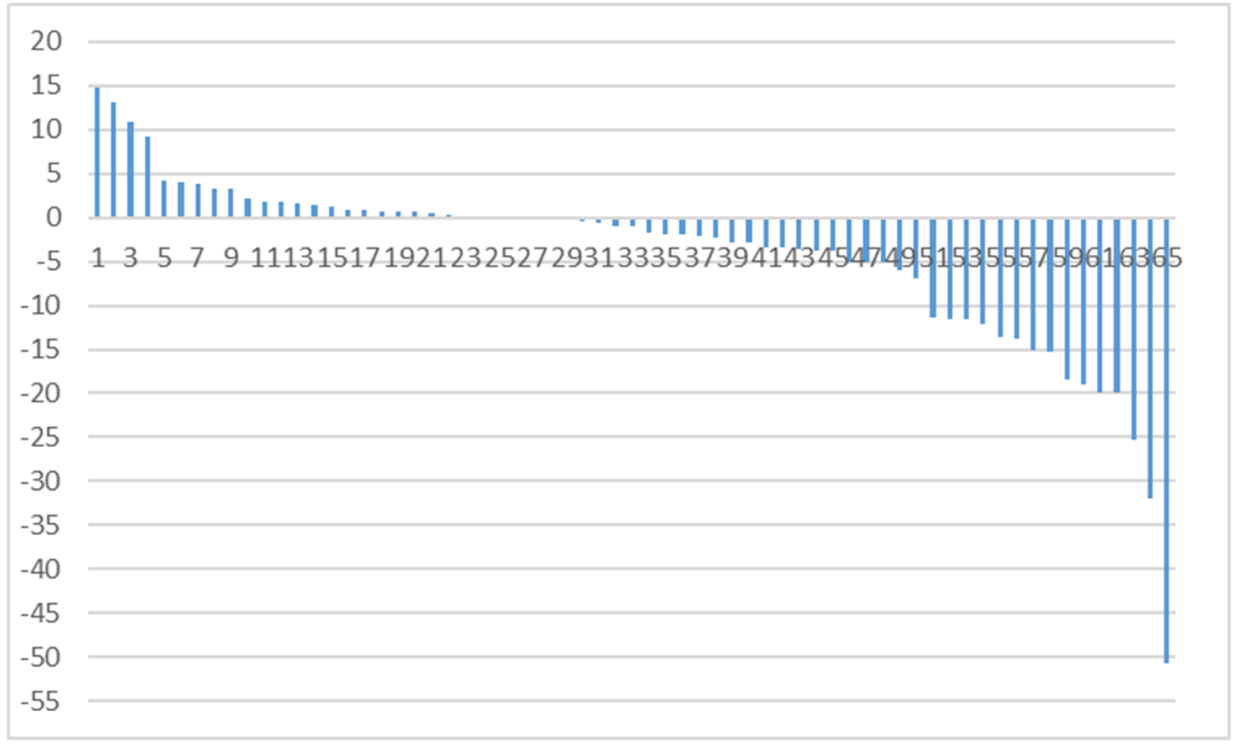

Figure 2: Percentage variances $\geq 5 \%$ : all case types

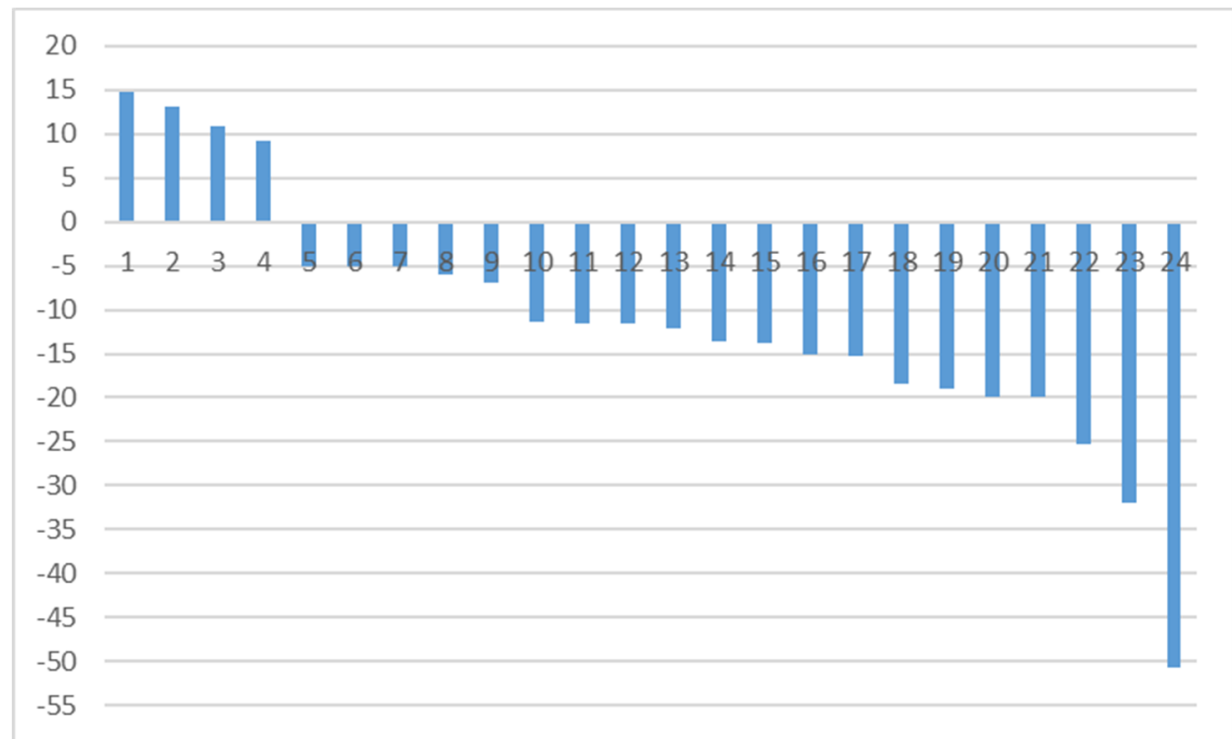

Second, as with the figure for all case types, most Justices' dissent/special concurrence patterns in criminal cases did not vary significantly. See Figure 3. Only fifteen Justices had a variance equal to or greater than $5 \%$. Eleven of those Justices dissented/specially concurred in a smaller percentage of cases during the year after the re-selection event than before. See Figure 4. This pattern further supports the idea that a Justice may write separately more often before a re- 
selection event than after to better explain his decisions to those having a say in the Justice keeping his job.

Figure 3: Percentage variances for criminal cases.

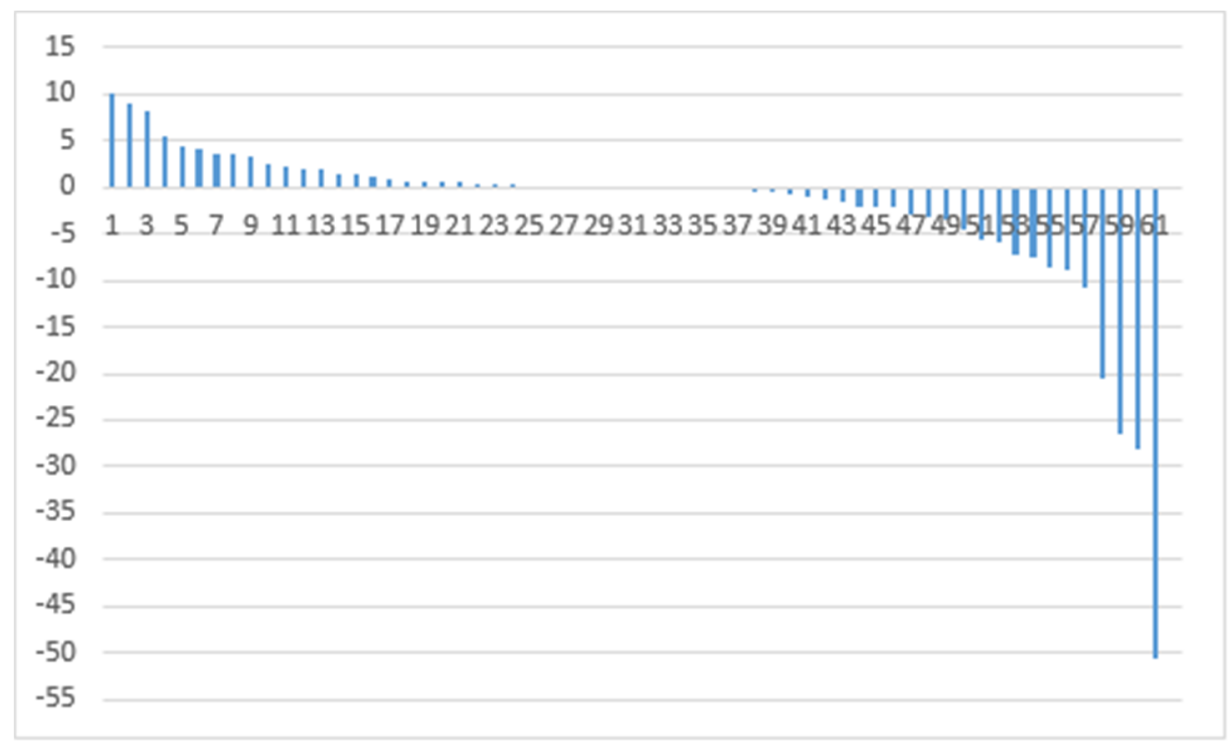

Figure 4: Percentage variances $\geq 5 \%$ : criminal cases.

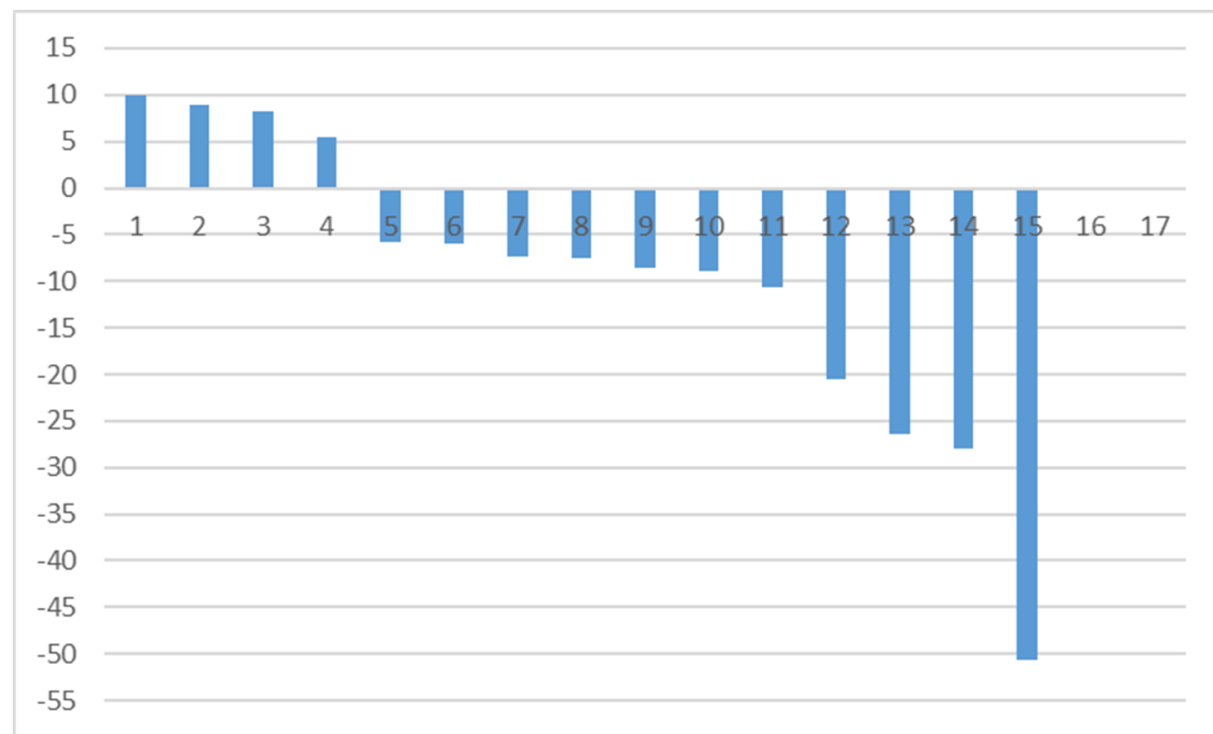

Third, the Justices re-selected through partisan elections had greater percentage variances in dissents/special concurrences than Justices re-selected by other methods. See Tables 2-4. Nine of the thirteen Justices re-elected in partisan races had variances equal to or greater than $5 \%$. And all but one Justice wrote or joined a smaller percentage of dissents/special concurrences in the year after the 
election. See Figure 5. Similarly, five of the nine Justices who decided criminal cases had variances equal to or greater than $5 \%$ and predominantly filed a smaller percentage of dissents/special concurrences in the year after the election. See Figure 6.

Figure 5: Percentage variance all case types: partisan elections.

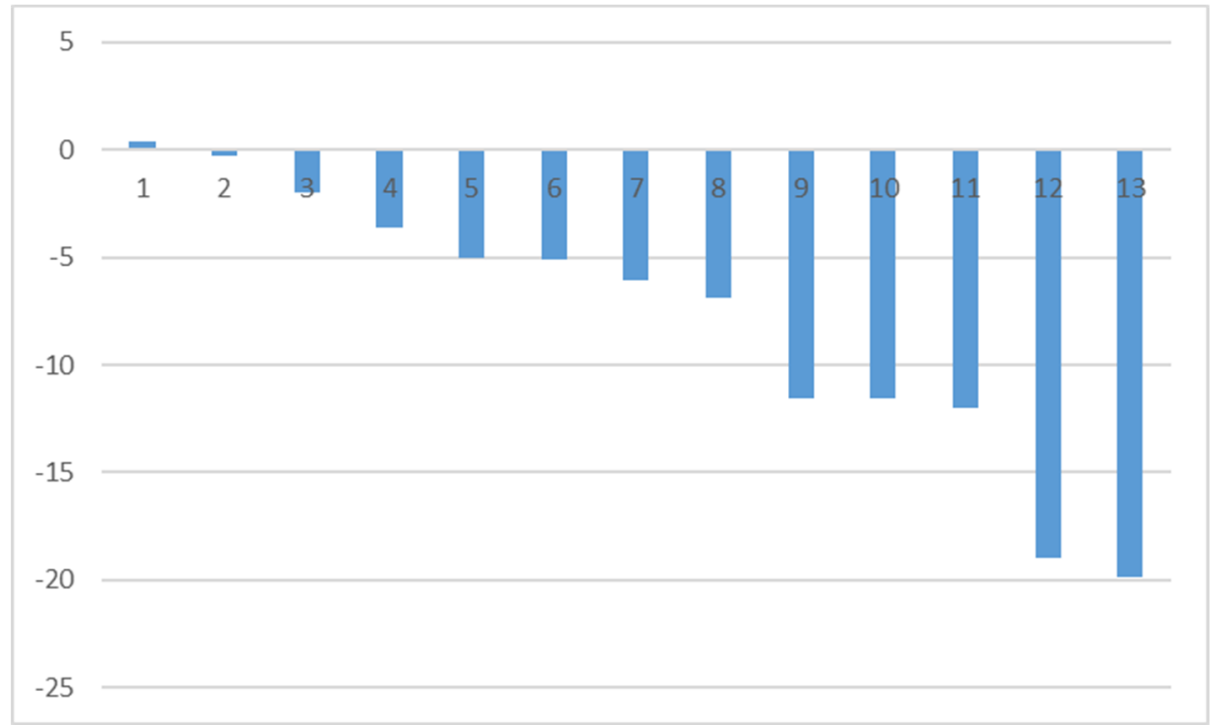

Figure 6: Percentage variances criminal cases: partisan elections

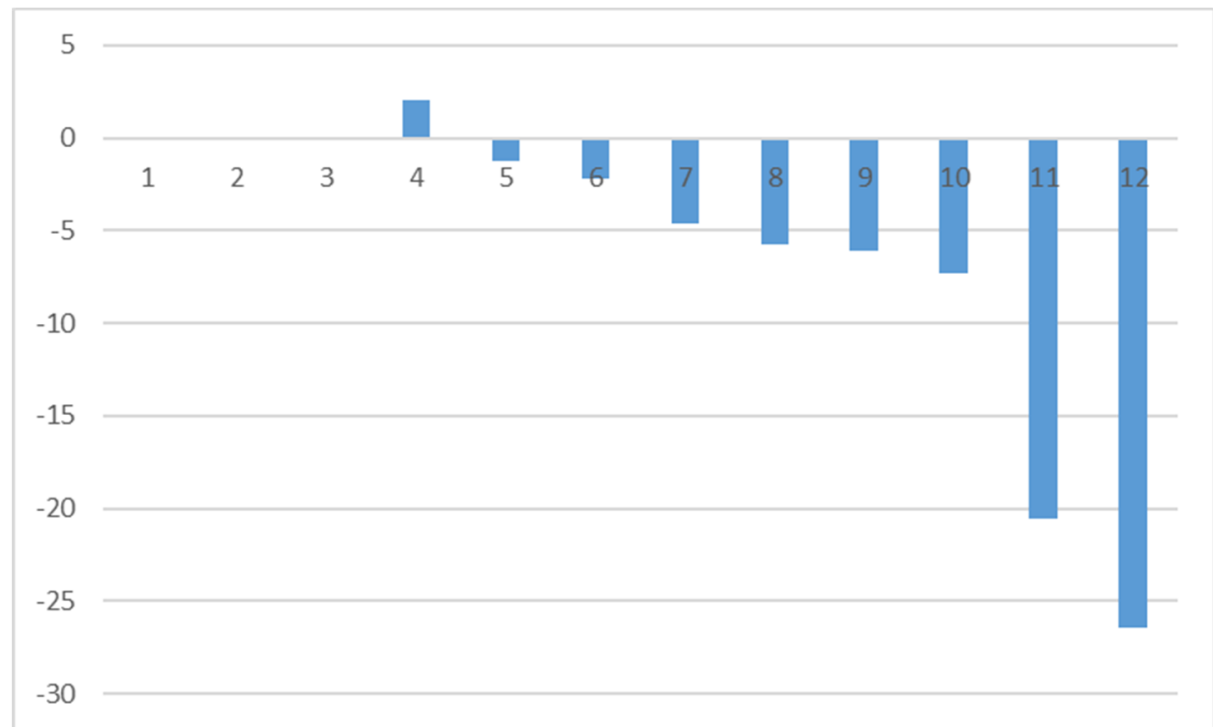

Justices re-selected in non-partisan elections had fewer percentage variances than their peers running in partisan elections. Only six of the twenty-one Justices 
in this group had variances of $5 \%$ or more. Of these six, true to the emerging pattern, five wrote or joined in a smaller percentage of dissents/special concurrences during the year after the election. See Figure 7. Examining dissents/special concurrences in criminal cases yielded similar results. Only four of the Justices had variances equal to or greater than 5\% with three writing or joining a smaller percentage of dissents/special concurrences in the year after the election. See Figure 8.

Figure 7: Percentage variance all case types: non-partisan elections

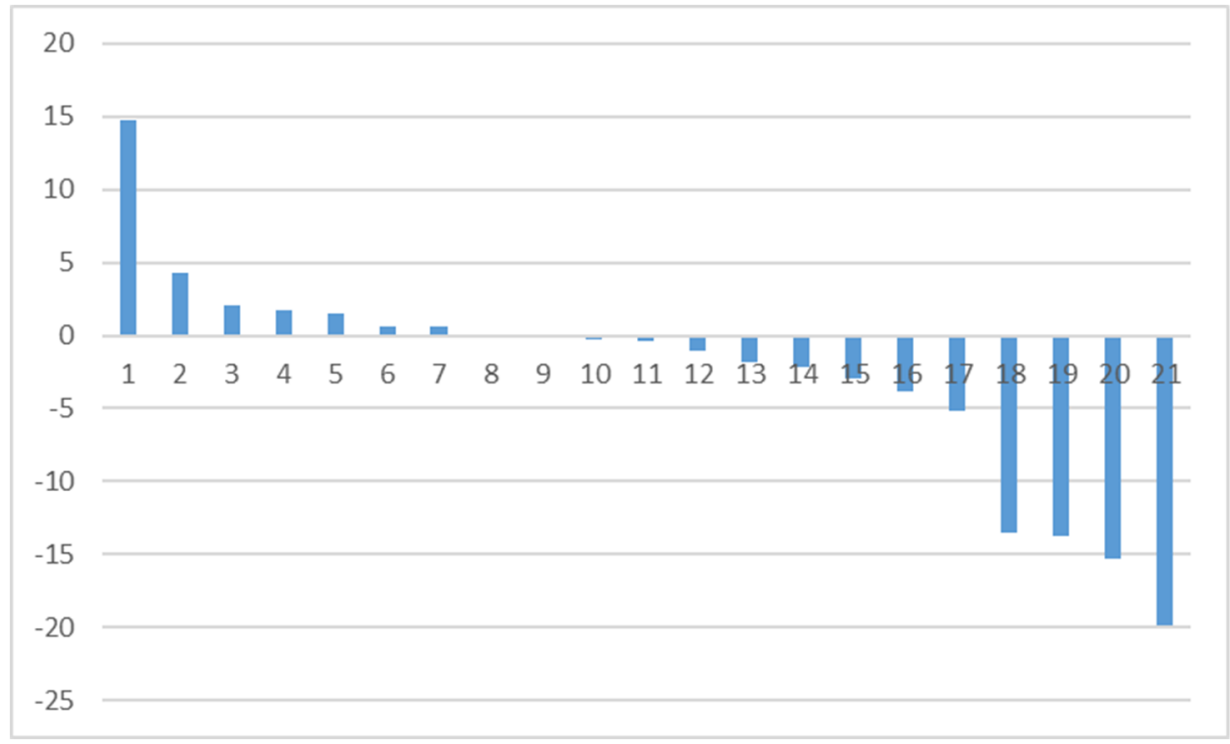


Figure 8: Percentage variances criminal cases: non-partisan elections

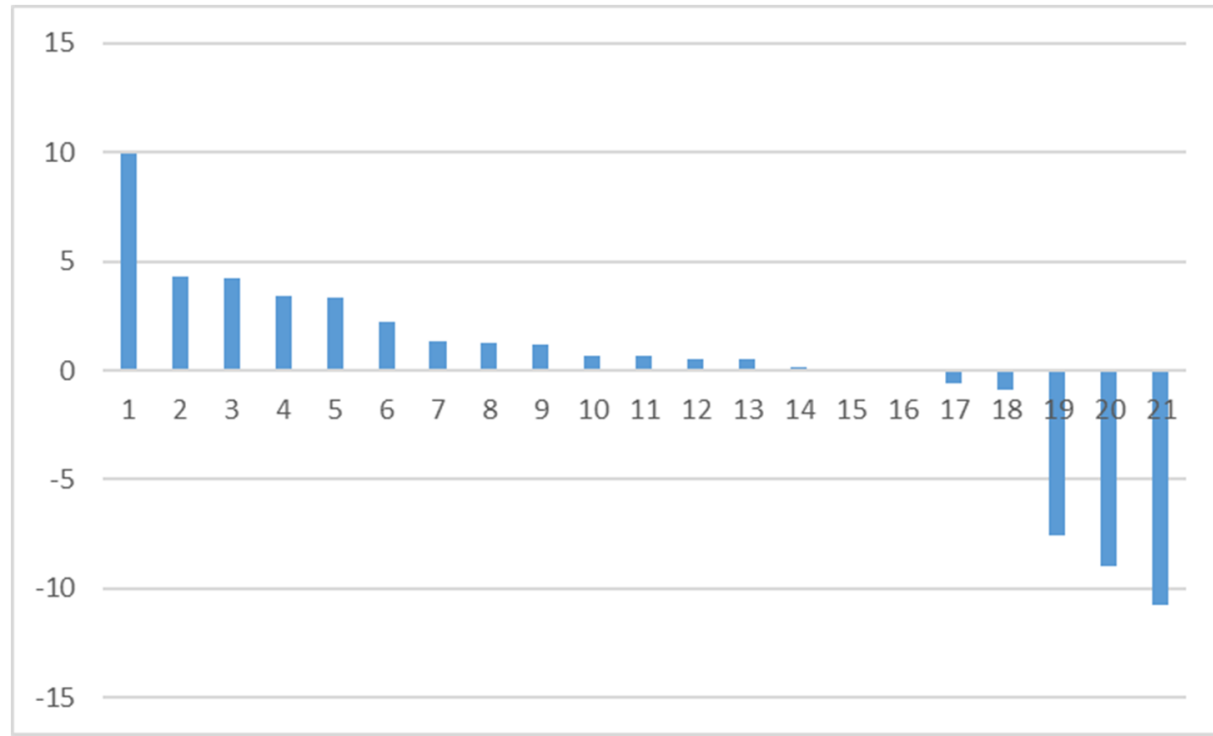

The results for Justices re-selected in retention elections or by reappointments mimicked the results for Justices who ran in non-partisan elections. Nine of the thirty-one Justices who ran in retention elections or who were reappointed had percentage variance rates equal to or greater than $5 \%$. Six of these nine wrote or joined in a smaller percentage of dissents/special concurrences in the year following re-selection. See Figure 9. Similarly, only six Justices had variances rates equal to or greater than $5 \%$ in criminal cases, with half writing or joining more dissents/special concurrences before the re-selection event and half after the event. See Figure 10. 
Figure 9: Percentage variance all case types: retention elections/re-appointment.

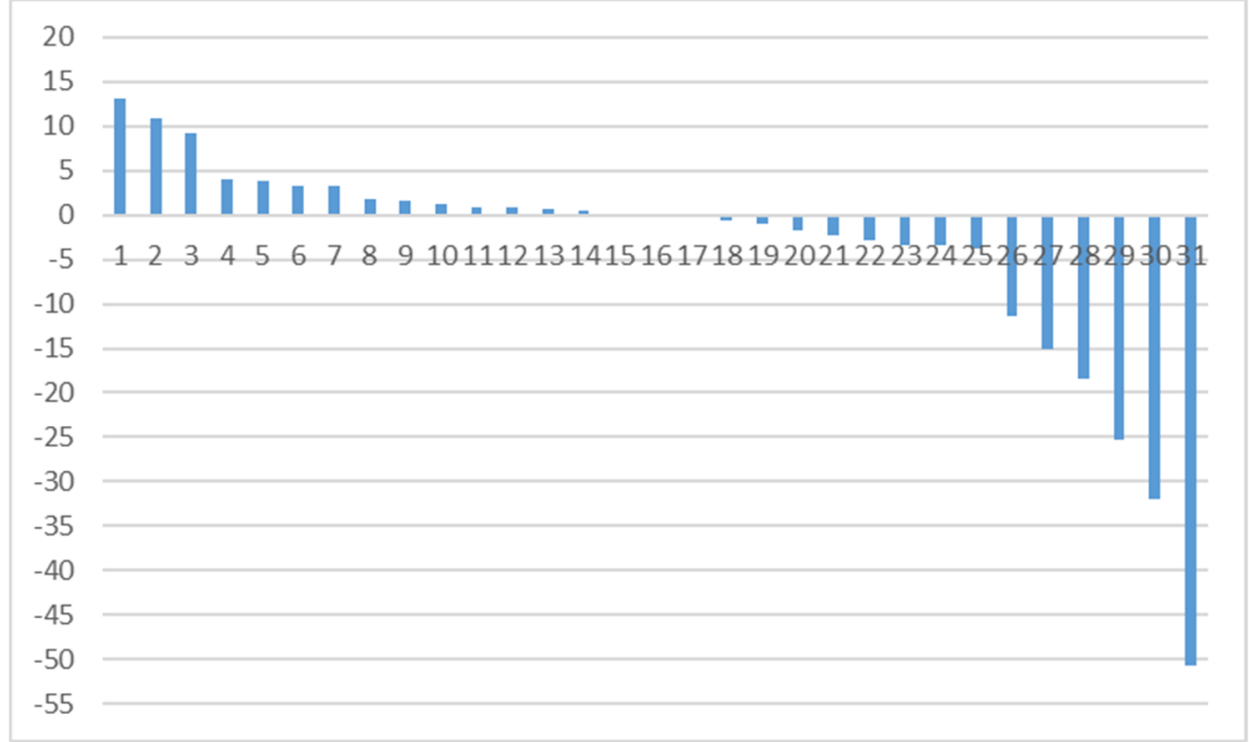

Figure 10: Percentage variances criminal cases: retention elections/reappointment.

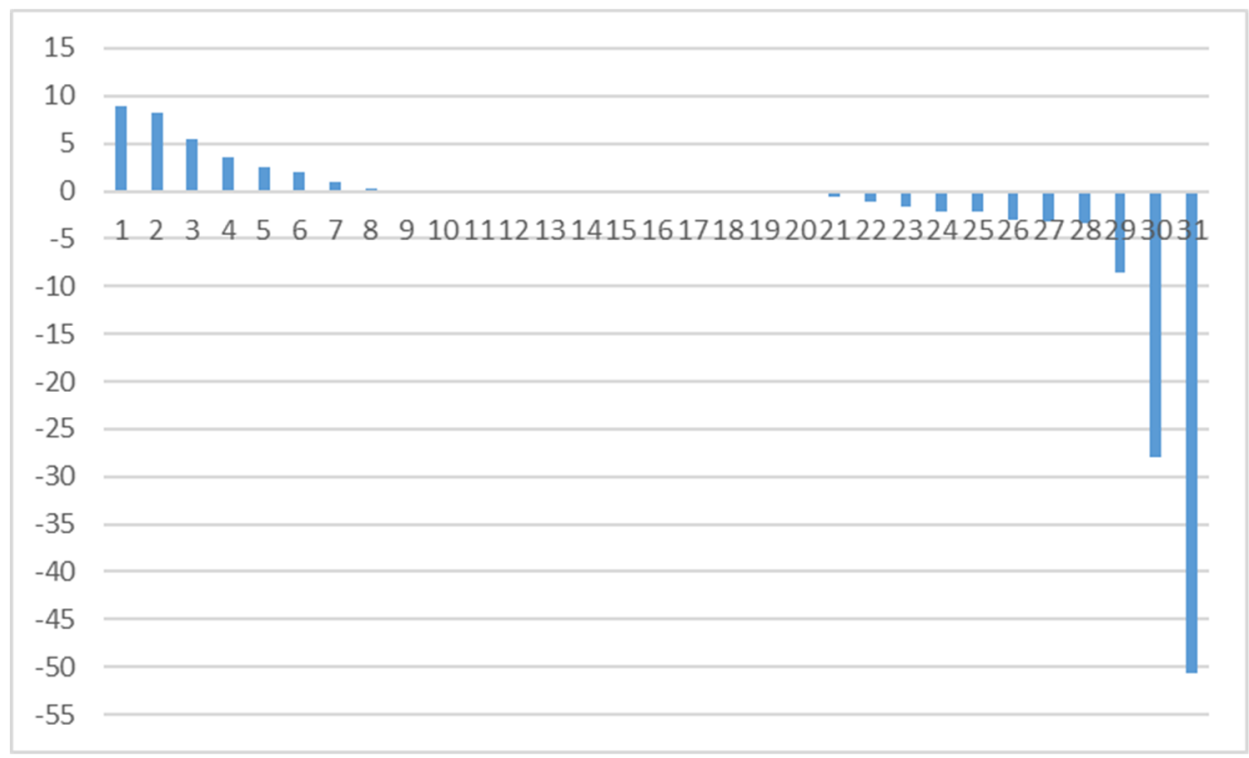

The data suggests that the sub-hypothesis is true for many Justices but not the majority. It also appears that Justices who ran in partisan elections were more apt to consider an upcoming election when deciding whether to write or join a dissent/special concurrence than Justices re-selected using other methods. Finally, the Justices who had a percentage variance of $5 \%$ or more tended to write 
or join a smaller percentage of dissents/special concurrences the year following re-selection. This finding evidences what some Justices related in the interviews about their preferences to write separately in a case to better explain a decision to voters or others responsible for re-selecting the Justice.

\section{$\mathrm{V}$ \\ CONCLUSION}

The information gained through the interviews and the empirical data obtained by examining dissent/special concurrence rates in the years immediately preceding and following 2014 re-selection events suggest that the major hypothesis is true. The re-selection methods-elections and reappointmentsimposed on most state Supreme Court Justices tempt them to act strategically to maximize their prospects of maintaining their positions. But while re-selection events may create a temptation for Justices to make decisions in a way that preserves their positions, it is a temptation that is generally ignored.

Justices' concerns about keeping their jobs are omnipresent, but most have come to terms with the prospect of losing their jobs and use tactics to compartmentalize their personal welfare concerns when making decisions. These Justices can prioritize the importance of the rule of law and an independent judiciary. Other Justices slip from time to time, particularly in the run up to a reselection event, and are consciously or unconsciously strategic in their decision making.

Although the empirical data regarding dissents/special concurrences suggests that Justices who run in partisan elections are most at risk for yielding to the temptation to act with personal benefits in mind, all Justices subject to reselection are at risk. Based on my personal observations and the reflections of several of the interviewed Justices, it seems that the character of the Justice will matter most in determining whether he can resist the temptation. 


\section{APPENDIX}

Table 1: Dissent/Special Concurrence rates year before/after 2014 re-selection event.

\begin{tabular}{|c|c|c|c|c|c|}
\hline Justices & Method & $\begin{array}{c}\% \\
\text { year } 1\end{array}$ & $\begin{array}{c}\% \\
\text { year } 2\end{array}$ & $\begin{array}{c}\% \\
\text { Var. }\end{array}$ & $\%$ CR Var \\
\hline 1 & PE & 73.91 & 74.28 & 0.37 & -20.56 \\
\hline 2 & $\mathrm{RE}$ & 4.79 & 2.5 & -2.29 & -0.24 \\
\hline 3 & $\mathrm{RE}$ & 0 & 3.84 & 3.84 & 0 \\
\hline 4 & NPE & 8.69 & 7.69 & -1 & 4.34 \\
\hline 5 & PE & 51.85 & 32 & $\overline{19.85}$ & -26.46 \\
\hline 6 & $\mathrm{RE}$ & 22.91 & 19.14 & -3.77 & 0.22 \\
\hline 7 & $\mathrm{RE}$ & 34.69 & 23.4 & 11.29 & -1.08 \\
\hline 8 & $\mathrm{RE}$ & 8.97 & 22 & 13.03 & 8.16 \\
\hline 9 & $\mathrm{RE}$ & 0 & 4 & 4 & 2 \\
\hline 10 & NPE & 9.6 & 13.86 & 4.26 & 0.53 \\
\hline 11 & NPE & 6.89 & 7 & -0.11 & 3.42 \\
\hline 12 & NPE & 2.4 & 3.03 & 0.63 & 2.23 \\
\hline 13 & NPE & 2.38 & 3.79 & 1.52 & 1.26 \\
\hline 14 & NPE & 5.95 & 3.79 & 2.16 & 1.34 \\
\hline 15 & PE & 14.7 & 11.11 & 3.59 & 6.05 \\
\hline 16 & $\mathrm{RE}$ & 12.19 & 23.07 & 10.88 & 2.56 \\
\hline 17 & $\mathrm{RE}$ & 9.75 & 10.25 & 0.5 & 5.38 \\
\hline 18 & $\mathrm{RE}$ & 4.49 & 15 & 3.34 & 8.84 \\
\hline 19 & $\mathrm{RE}$ & 16.85 & 18.64 & 1.75 & 2.18 \\
\hline 20 & NPE & 16.41 & 2.7 & 13.71 & 7.6 \\
\hline 21 & NPE & 23.88 & 4.05 & 19.83 & 10.73 \\
\hline 22 & NPE & 14.92 & 1.35 & 13.57 & 8.95 \\
\hline 23 & NPE & 0 & 0 & 0 & 0 \\
\hline 24 & REAPPT & 4.68 & 4.54 & 0.14 & 1.56 \\
\hline 25 & $\mathrm{RE}$ & 15.25 & 24.52 & 9.27 & 3 \\
\hline 26 & PE & 18.42 & 13.33 & 5.09 & 1.23 \\
\hline 27 & PE & 32.43 & 13.33 & 18.97 & 7.33 \\
\hline 28 & NPE & 10.16 & 8.33 & 1.83 & 3.31 \\
\hline
\end{tabular}




\begin{tabular}{|c|c|c|c|c|c|}
\hline 29 & NPE & 13.55 & 28.33 & 14.78 & 9.95 \\
\hline 30 & $\mathrm{RE}$ & 33.33 & 8 & 25.33 & 8.5 \\
\hline 31 & $\mathrm{RE}$ & 36 & 4 & 32 & 28 \\
\hline 32 & NPE & 10.71 & 11.34 & 0.63 & 0.69 \\
\hline 33 & NPE & 5.71 & 7.8 & 2.09 & 0.7 \\
\hline 34 & $\mathrm{RE}$ & 0 & 1.69 & 1.69 & 0 \\
\hline 35 & NPE & 4.98 & 6.72 & 1.74 & 1.18 \\
\hline 36 & NPE & 4.25 & 4 & 0.25 & 0 \\
\hline 37 & REAPPT & 7.81 & 8.45 & 0.64 & 3.12 \\
\hline 38 & $\mathrm{RE}$ & 1.85 & 1.96 & 0.11 & 0.11 \\
\hline 39 & $\mathrm{PE}$ & 26.31 & 14.28 & 12.03 & 5.76 \\
\hline 40 & $\mathrm{PE}$ & 13.63 & 13.33 & 0.3 & 4.65 \\
\hline 41 & $\mathrm{PE}$ & 9.09 & 2.22 & 6.87 & 2.22 \\
\hline 42 & $\mathrm{PE}$ & 27.27 & 22.22 & 5.05 & 2.02 \\
\hline 43 & NPE & 18.75 & 14.89 & 3.86 & 0.86 \\
\hline 44 & NPE & 18.55 & 15.62 & 2.93 & 0.16 \\
\hline 45 & $\mathrm{RE}$ & 44.44 & 25.92 & 18.52 & 0 \\
\hline 46 & $\mathrm{RE}$ & 10.34 & 10.34 & 0 & 0 \\
\hline 47 & $\mathrm{RE}$ & 55.17 & 40 & 15.17 & 0 \\
\hline 48 & $\mathrm{RE}$ & 66.66 & 10 & 50.66 & 50.66 \\
\hline 49 & $\mathrm{RE}$ & 5.08 & 2.17 & 2.91 & 0 \\
\hline 50 & $\mathrm{RE}$ & 11.86 & 10.86 & 1 & 3.61 \\
\hline 51 & $\mathrm{RE}$ & 4.25 & 0.91 & 3.34 & 2.12 \\
\hline 52 & $\mathrm{RE}$ & 3.44 & 0 & 3.44 & 3.44 \\
\hline 53 & $\mathrm{RE}$ & 1.06 & 1.9 & 0.84 & 0.11 \\
\hline 54 & $\mathrm{RE}$ & 2.27 & 3.22 & 0.95 & 0.95 \\
\hline 55 & $\mathrm{RE}$ & 0 & 1.63 & 1.63 & 0 \\
\hline 56 & $\mathrm{PE}$ & 5.66 & 3.7 & 1.96 & $\mathrm{n} / \mathrm{a}$ \\
\hline 57 & $\mathrm{PE}$ & 11.53 & 0 & 11.53 & $\mathrm{n} / \mathrm{a}$ \\
\hline 58 & $\mathrm{PE}$ & 18.96 & 7.4 & 11.56 & $\mathrm{n} / \mathrm{a}$ \\
\hline 59 & PE & 11.32 & 5.26 & 6.06 & $\mathrm{n} / \mathrm{a}$ \\
\hline 60 & $\mathrm{RE}$ & 6.66 & 17.46 & 3.32 & 0.16 \\
\hline 61 & NPE & 23.72 & 8.45 & 15.27 & 0.55 \\
\hline
\end{tabular}




\begin{tabular}{|c|c|c|c|c|c|}
\hline 62 & NPE & 18.64 & 18.3 & 0.34 & 4.2 \\
\hline 63 & NPE & 22.03 & 16.9 & 5.13 & 0.6 \\
\hline 64 & RE & 0 & 1.26 & 1.26 & 0 \\
\hline 65 & RE & 1.29 & 0.63 & 0.66 & 0.64 \\
\hline
\end{tabular}

Table 2: Dissent/Special Concurrence rates year before/after 2014 re-selection event-partisan elections.

\begin{tabular}{|r|l|r|r|r|r|}
\hline \multicolumn{1}{|l|}{ Justices } & Method & \% year 1 & \% year 2 & \multicolumn{1}{|c|}{ \% Var. } & \multicolumn{2}{l|}{ Var } \\
\hline 1 & PE & 73.91 & 74.28 & 0.37 & -20.56 \\
\hline 5 & PE & 51.85 & 32 & -19.85 & -26.46 \\
\hline 15 & PE & 14.7 & 11.11 & -3.59 & -6.05 \\
\hline 26 & PE & 18.42 & 13.33 & -5.09 & -1.23 \\
\hline 27 & PE & 32.43 & 13.33 & -18.97 & -7.33 \\
\hline 39 & PE & 26.31 & 14.28 & -12.03 & -5.76 \\
\hline 40 & PE & 13.63 & 13.33 & -0.3 & -4.65 \\
\hline 41 & PE & 9.09 & 2.22 & -6.87 & -2.22 \\
\hline 42 & PE & 27.27 & 22.22 & -5.05 & 2.02 \\
\hline 56 & PE & 5.66 & 3.7 & -1.96 & n/a \\
\hline 57 & PE & 11.53 & 0 & -11.53 & n/a \\
\hline 58 & PE & 18.96 & 7.4 & -11.56 & n/a \\
\hline 59 & PE & 11.32 & 5.26 & -6.06 & n/a \\
\hline & & & & & \\
\hline
\end{tabular}


Table 3: Dissent/Special Concurrence rates year before/after 2014 re-selection event-non-partisan elections.

\begin{tabular}{|c|c|c|c|c|c|}
\hline Justices & Method & $\%$ year 1 & \% year 2 & \% Var. & $\begin{array}{l}\% \text { CR } \\
\text { Var }\end{array}$ \\
\hline 4 & NPE & 8.69 & 7.69 & -1 & 4.34 \\
\hline 10 & NPE & 9.6 & 13.86 & 4.26 & 0.53 \\
\hline 11 & NPE & 6.89 & 7 & -0.11 & 3.42 \\
\hline 12 & NPE & 2.4 & 3.03 & 0.63 & 2.23 \\
\hline 13 & NPE & 2.38 & 3.79 & 1.52 & 1.26 \\
\hline 14 & NPE & 5.95 & 3.79 & -2.16 & 1.34 \\
\hline 20 & NPE & 16.41 & 2.7 & -13.71 & -7.6 \\
\hline 21 & NPE & 23.88 & 4.05 & -19.83 & -10.73 \\
\hline 22 & NPE & 14.92 & 1.35 & -13.57 & -8.95 \\
\hline 23 & NPE & 0 & 0 & 0 & 0 \\
\hline 28 & NPE & 10.16 & 8.33 & -1.83 & 3.31 \\
\hline 29 & NPE & 13.55 & 28.33 & 14.78 & 9.95 \\
\hline 32 & NPE & 10.71 & 11.34 & 0.63 & 0.69 \\
\hline 33 & NPE & 5.71 & 7.8 & 2.09 & 0.7 \\
\hline 35 & NPE & 4.98 & 6.72 & 1.74 & 1.18 \\
\hline 36 & NPE & 4.25 & 4 & -0.25 & 0 \\
\hline 43 & NPE & 18.75 & 14.89 & -3.86 & -0.86 \\
\hline 44 & NPE & 18.55 & 15.62 & -2.93 & 0.16 \\
\hline 61 & NPE & 23.72 & 8.45 & -15.27 & 0.55 \\
\hline 62 & NPE & 18.64 & 18.3 & -0.34 & 4.2 \\
\hline 63 & NPE & 22.03 & 16.9 & -5.13 & -0.6 \\
\hline
\end{tabular}


Table 4: Dissent/Special Concurrence rates year before/after 2014 re-selection event - retention elections/re-appointments.

\begin{tabular}{|c|c|c|c|c|c|}
\hline Justices & Method & $\%$ year 1 & $\%$ year 2 & $\%$ Var. & $\begin{array}{l}\text { \% CR } \\
\text { Var } \\
\end{array}$ \\
\hline 2 & $\mathrm{RE}$ & 4.79 & 2.5 & -2.29 & -0.24 \\
\hline 3 & $\mathrm{RE}$ & 0 & 3.84 & 3.84 & 0 \\
\hline 6 & $\mathrm{RE}$ & 22.91 & 19.14 & -3.77 & 0.22 \\
\hline 7 & RE & 34.69 & 23.4 & -11.29 & -1.08 \\
\hline 8 & $\mathrm{RE}$ & 8.97 & 22 & 13.03 & 8.16 \\
\hline 9 & $\mathrm{RE}$ & 0 & 4 & 4 & 2 \\
\hline 16 & $\mathrm{RE}$ & 12.19 & 23.07 & 10.88 & 2.56 \\
\hline 17 & $\mathrm{RE}$ & 9.75 & 10.25 & 0.5 & 5.38 \\
\hline 18 & $\mathrm{RE}$ & 4.49 & 15 & 3.34 & 8.84 \\
\hline 19 & $\mathrm{RE}$ & 16.85 & 18.64 & 1.75 & -2.18 \\
\hline 24 & REAPPT & 4.68 & 4.54 & -0.14 & -1.56 \\
\hline 25 & $\mathrm{RE}$ & 15.25 & 24.52 & 9.27 & -3 \\
\hline 30 & $\mathrm{RE}$ & 33.33 & 8 & -25.33 & -8.5 \\
\hline 31 & $\mathrm{RE}$ & 36 & 4 & -32 & -28 \\
\hline 34 & $\mathrm{RE}$ & 0 & 1.69 & -1.69 & 0 \\
\hline 37 & REAPPT & 7.81 & 8.45 & 0.64 & -3.12 \\
\hline 38 & $\mathrm{RE}$ & 1.85 & 1.96 & 0.11 & 0.11 \\
\hline 45 & $\mathrm{RE}$ & 44.44 & 25.92 & -18.52 & 0 \\
\hline 46 & $\mathrm{RE}$ & 10.34 & 10.34 & 0 & 0 \\
\hline 47 & $\mathrm{RE}$ & 55.17 & 40 & -15.17 & 0 \\
\hline 48 & $\mathrm{RE}$ & 66.66 & 10 & -50.66 & -50.66 \\
\hline 49 & $\mathrm{RE}$ & 5.08 & 2.17 & -2.91 & 0 \\
\hline 50 & $\mathrm{RE}$ & 11.86 & 10.86 & -1 & 3.61 \\
\hline 51 & $\mathrm{RE}$ & 4.25 & 0.91 & -3.34 & -2.12 \\
\hline 52 & $\mathrm{RE}$ & 3.44 & 0 & -3.44 & -3.44 \\
\hline 53 & $\mathrm{RE}$ & 1.06 & 1.9 & 0.84 & -0.11 \\
\hline 54 & $\mathrm{RE}$ & 2.27 & 3.22 & 0.95 & 0.95 \\
\hline 55 & $\mathrm{RE}$ & 0 & 1.63 & 1.63 & 0 \\
\hline 60 & $\mathrm{RE}$ & 6.66 & 17.46 & 3.32 & -0.16 \\
\hline 64 & $\mathrm{RE}$ & 0 & 1.26 & 1.26 & 0 \\
\hline 65 & $\mathrm{RE}$ & 1.29 & 0.63 & -0.66 & -0.64 \\
\hline
\end{tabular}

